\title{
Land Tenure, Land Tax and Social Conflictuality in Iraq from the Late Sasanian to the Early Islamic Period (Fifth to Ninth Centuries CE)
}

\author{
Michele Campopiano
}

Different sources have allowed us to study land tenure and land administration in late Sasanian and early Islamic Iraq. Narrative and juridical sources had already shed light on these aspects of social and economic life of the Middle East, as shown by studies such those of Michael Morony. ${ }^{1}$ For the late Sasanian period, further assistance has come from new editions of the Hazār Dādestān, or A Thousand Judgements, commonly referred to as Mādayān ì Hazār Dādestān, or Book of a Thousand Judgements, a collection of Sasanian legal cases from the first half of the seventh century. ${ }^{2}$ Numismatic and sigillographic evidence has also aided historians in reconstructing the administration of the empire. ${ }^{3}$ In fact our position as historians of land tenure in early medieval Iraq differs little from that of our colleagues studying patterns of landholding in early medieval Europe where the sources, in terms of their quantity and nature, are comparable. ${ }^{4}$ We can draw further comparison on the basis of surviving

1 Michael G. Morony, "Landholding in Seventh-Century Iraq: Late Sasanian and Early Islamic Patterns," in The Islamic Middle East, 700-19oo: Studies in Economic and Social History, ed. Abraham L. Udovitch (Princeton: Darwin Press, 1981), 135-175; Michael G. Morony, "Landholding and Social Change: Lower al- 'Iraq in the Early Islamic Period," in Land Tenure and Social Transformation in the Middle East, ed. Tarif Khalidi (Beirut: American University of Beirut Press, 1984), 209-222; Michael G. Morony and Khodad Rezakhani, "Markets for Land, Labour and Capital in Late Antique Iraq, AD 200-700," Journal of Economic and Social History of the Orient 57 (2014): 231-261.

2 See Maria Macuch, Rechtskasuistik und Gerichtspraxis zu Beginn des siebenten Jahrhunderts in Iran: die Rechstsammlung des Farrohmard i Wahrāmān (Wiesbaden: Harrassowitz, 1993), 1-15. The edition and commentary by Maria Macuch represents the best tool we have to investigate this collection of legal cases but, since the author gives a transliteration rather than a transcription of the text, I will also refer to: Farraxvmart i Vahrāman, The Book of a Thousand Judgments (a Sasanian Law-Book), ed. Anahit G. Perikhanian (Costa Mesa: Mazda Publishers, 1997). I used David N. MacKenzie, A Concise Pahlavi Dictionary (London: Oxford University Press, 1971) to check the transcription.

3 See, for example: Rika Gyselen, La géographie administrative de l'empire sassanide: les témoignages sigillographiques (Paris: Groupe pour l' étude de la civilisation au Moyen Orient, 1989).

4 For a general impression we can look at Chris Wickham, Framing the Early Middle Ages: 
Pahlavi documents such as those of the Berkeley or Berlin archives, ${ }^{5}$ which date back probably to the Early Islamic period, ${ }^{6}$ or the thirty-two administrative and legal documents dated between 755 and 777 and originating in Khurasan, studied by Khan. ${ }^{7}$ Further comparison can be established with the wealth of documents originating from late Antique and early Islamic Egypt, although we have to keep in mind this area was under Byzantine rather than Sasanian rule (being conquered by the Persian for just a few years). ${ }^{8}$

These sources have allowed us to develop our understanding of land tenure and land tax administration. As I have shown in a preceding paper, land tenure in early medieval Iraq should be analysed in connection with the evolution of land tax. I have demonstrated that the idea of the tributary mode of production, as defined by Byzantinist John Haldon, ${ }^{9}$ can be used as an heuristic tool to analyse the predominant relations of production in early medieval Iraq $\cdot{ }^{10} \mathrm{In}$

Europe and the Mediterranean (Oxford: Oxford University Press, 2005), 259-302 and 383441. This book offers a wide comparison of rural societies and rural economies in the post-Roman world.

5 See for example: Michele Campopiano, "L' administration des impôts en Irak et Iran de la fin de l'époque Sassanide à la crise du califat Abbaside (vie-xe siècles)," in Lo que vino de Oriente, eds. X. Ballestin and E. Pastor, British Archaeological Reports International Series 2525 (Oxford: Archaeopress, 2013), 17-27.

6 The Pahlavi documents (from the seventh century) at the Bancroft Library at the University of California, Berkeley, which are being studied and edited by Philippe Gignoux and Rika Gyselen, will help to shed more light on aspects of the administration between the late Sasanian Empire and the early Islamic Period: Philippe Gignoux, "Aspects de la vie administrative et sociale en Iran du 7ème siècle," in Contributions à l'histoire et la géographie historique de l'empire Sassanide, ed. Rika Gyselen (Bures-sur-Yvette: Groupe pour l'étude de la civilisation au Moyen Orient, 2004), 37-48; Philippe Gignoux, "Une nouvelle collection de documents en pehlevi cursif du début du VII ${ }^{\mathrm{e}}$ siècle de notre ère," Comptes-rendus de l'Académie des inscriptions et belles-lettres 135, no. 4 (1991): 683-70o; Dieter Weber, Myriam Krutzsch and Maria Macuch, Berliner Pahlavi-Dokumente. Zeugnisse spätsassanidischer Brief- und Rechtskultur aus frühislamischer Zeit (Wiesbaden: Harrassowitz, 2008).

7 Geoffrey Khan, Arabic Documents from Early Islamic Khurasan (London: Khalili Collections, 2007); Geoffrey Khan, "Newly Discovered Arabic Documents from Early Abbasid Khurasan," in From al-Andalus to Khurasan: Documents from the Medieval Muslim World, eds. Petra M. Sijpesteijn, Lennart Sundelin, Sofia Torallas Tovar and Amalia Zomeño (Leiden: Brill, 2006), 201-215.

8 See for example Petra M. Sijpesteijn, Shaping a Muslim State: The World of a Mid-EighthCentury Egyptian Official (Oxford: Oxford University Press, 2013).

9 John Haldon, The State and the Tributary Mode of Production (London/New York: Verso, 1993), 65-67 and $75^{-87}$.

10 Michele Campopiano, "Alā l-misāḥa and muqāsama Land Tax: Legal Theory and Balance of Social Forces in Early Medieval Iraq (Sixth to Eighth Centuries)," Journal of the Economic and Social History of the Orient 54 (2011): 239-269. 
this usage 'relations of production' should be understood as the ways in which the means of production are controlled, and the relationship between direct producers and those means, as well as between the producers and their own labor power. The tributary mode of production is based on a system of surplus extraction from peasant production that ultimately relies on coercion. 'Tax' and 'rent' are two possible forms taken by this coercive surplus extraction. Therefore, there is no economic difference between the two concepts: "For both sides of the couplet tax/rent are, in fact, expressions of the political-juridical forms that surplus appropriation takes, not distinct modes [of production]."11

This perspective also offers new insights into the relationship between patterns of surplus extraction, as expressed in the couplet tax/rent, and social conflicts. Social conflicts in the tributary mode of production can be caused by the contra-position of the exploiting classes and the exploited class (producers), from whom the surplus is extracted in the form of taxes and rents. Alternatively, conflicts may arise from the contra-position of different social groups within the ruling classes regarding access to the surplus in the form of rents or salaries paid from the taxes. The ruling class can appropriate land surplus by taking control of portions of land and therefore receiving rents paid by the peasants cultivating the land (for example in the Carolingian empire) or by redistributing taxes to a ruling group in the form of salary (as in the case of payment to Arabs after the conquest). ${ }^{12}$

Social conflicts cannot be defined solely on the basis of the socio-economic structure in which they arise, even if empirical analysis points to the inherent contradictions of this structure as the main background for these conflicts. The intellectual aspects of these conflicts, in terms of the various political or religious creeds that motivate violent rebellions or sublimate social conflicts into different systems of belief, should maintain a central position in our analysis. As Gramsci has pointed out, ideologies have considerable importance in shaping the ground upon which human groups organize themselves and acquire a consciousness of their position: they are the form while the material forces represent the content. ${ }^{13}$ Social entities have to be created and visions of the world contribute to the construction of the social world, as Bourdieu has written. ${ }^{14}$ We are somewhat better informed about the ideologies of social movements than about the economic and social forces prevailing in the period in question.

\footnotetext{
11 Haldon, The State, 77.

12 Haldon, 142-143, 203-218.

13 Antonio Gramsci, Quaderni dal Carcere, 4 vols. (Torino: Einaudi, 1975), 868-869.

14 Pierre Bourdieu, "The Social Space and the Genesis of Groups," Theory and Society 14 (1985): 23-744; Pierre Bourdieu, "Social Space and Symbolic Power," Sociological Theory 7 (1989): 14-25.
} 
However, we can, with caution, move from theories to the material issues from which they arose. We need to consider the intellectual traditions within which these ideologies were shaped, and moreover, we need to proceed through a critical analysis of the sources we are using. In particular, in the case of early medieval Iraq, we must recognize that nothing, or almost nothing, remains of the writings of the many opposition groups who had lost their struggle for power: knowledge of their ideology was largely mediated by hostile sources our sources originate in a male, urban, elite milieu. We do not have access to the voice of the subordinates. Hobsbawm was able to include an appendix containing the voices of his nineteenth- and twentieth-century rebels in his Primitive Rebels, ${ }^{15}$ and the Italian anthropologist Ernesto de Martino was able to carry out fieldwork on the magic and religious thought of the subaltern peasantry of Southern Italy ${ }^{16}$ For us, similar operations (although methodologically problematic for every historian or anthropologist) are simply impossible.

On the basis of the general observations made in this introduction, I will try to delineate a general outline of the relationship between the evolution of land tenure and land tax, and social conflicts in early medieval Iraq between the late Sasanian period and the Zanğ (869-883) revolt. Moreover, my analysis will also consider how social conflicts provoked changes in the organization of land tenure and land tax. The social groups acting within a given economy and society cannot, of course, be seen as passive receptors of changes in patterns of land tenure and land tax administration. The very structure of the economy cannot exist without the groups that operate and maintain it: therefore processes of resistance and rebellion contribute to triggering processes of social and economic transformation.

\section{Kings, Aristocracy and Peasants in the Late Sasanian Empire}

From the fifth century CE land property in Sasanian Iraq seems to have become increasingly concentrated in large estates in the hands of the nobility. ${ }^{17}$ In the fifth and sixth centuries, land sales increasingly included entire village estates

\footnotetext{
15 Eric J. Hobsbawm, Primitive Rebels: Studies in Archaic Forms of Social Movement in the 19th and 2oth Centuries (Manchester: Manchester University Press, 1959), 175-193.

16 Ernesto De Martino, La terra del rimorso: Contributo a una storia religiosa del Sud (Milano: Il Saggiatore, 1961); Ernesto De Martino, Sud e magia (Milano: Feltrinelli, 1959).

17 Jairus Banaji, "Aristocracies, Peasantries and the Framing of the Early Middle Ages," Journal of Agrarian Change 9 (2009): 78-86; see also Khodadad Rezakhani and Michael G. Morony, "Markets for Land, Labour and Capital in Late Antique Iraq, AD 200-700," Journal of Economic and Social History of the Orient 57 (2014): 231-261.
} 
and their populations, and were progressively less concerned with individual fields. ${ }^{18}$ A subordinate peasantry cultivated these large estates according to different patterns of land tenure. Michael Morony has shown, through an analysis of the Babylonian Talmud, that the most common form of tenancy among Jews was sharecropping, with sharecroppers having a permanent lease of the land, although the presence of tenants who worked the land for a fixed annual quantity of produce is also attested. The latter were what Arabic sources called the $a k k a \bar{r}$, those who could lose their right to work the land if they failed to pay their rent. ${ }^{19}$ Forms of serfdom must have been common. Both the Talmud and Christian sources refer to entire villages and towns inhabited by 'slaves'. ${ }^{20}$ According to the Hazār Dādestān, the ownership of 'slaves' (anshahrīgan in Middle Persian) and cattle (stōr) transferred with the ownership of the estate on which they worked. ${ }^{21}$ Although the anshahrigan and the bandagan, another word usually translated as 'slaves,' could be sold individually, ${ }^{22}$ it is clear from this passage that a legal bond existed between an estate, its cattle (an important part of its capital), and its workforce.

Interestingly, according to the tradition reported by Abū Yūsuf (d. 798) after the conquest, caliph 'Umar b. al-Khaț̣āb (634-644) initially wanted to redistribute the land of the Sawād (the rural area of Iraq) among the Muslims, calculating that each of them could have received three 'peasants' (in Arabic fallāhün): thus a political constraint seemed to bind the peasantry to the land. ${ }^{23}$

Part of the surplus extracted from the peasantry was handed over to the state. Land tax seems to have been assessed on the basis of a share of the crops. ${ }^{24}$ Tax assessment based on a share of the crops depended largely on the crucial role of the nobility in collecting the tax in the area under their control, in handing over a share of it to the central authorities, and on an available and lucrative market for the authorities. ${ }^{25}$ This system did not allow for direct

\footnotetext{
18 Morony, "Landholding," 139.

19 Morony, 162-163.

20 Morony, 164.

21 Farraxvmart ī Vahrāman, The Book, 62-63; Macuch, Rechtskasuistik, 24-39.

22 Macuch, Rechtskasuistik, 34-35; MacKenzie, Pahlavi Dictionary, ad vocem.

23 Abū Yūsuf, Kitāb al-kharādj (Cairo: Būlāq, 1886), 21.

24 Zeev Rubin, "The Reforms of Khusrō Anūshirwān," in The Byzantine and Early Islamic Near East, vol. 3, States, Resources and Armies, ed. Averil Cameron (Princeton: Darwin Press, 1995), 232; Vladimir G. Lukonin, "Political, Social and Administrative Institutions: Taxes and Trade," in The Cambridge History of Iran, vol. 3, part 2, The Seleucid, Parthian and Sasanian Periods, ed. Ehsan Yarshater (Cambridge: Cambridge University Press, 1983), 745-746.

25 Zeev Rubin, "Nobility, Monarchy and Legitimation under the Later Sasanians," in The Byzantine and Early Islamic Near East, vol. 6, Elites Old and New in the Byzantine and Early Islamic Near East, eds. John Haldon and Lawrence I. Conrad (Princeton: Darwin Press,
} 
control by central government over tax collection and land administration: noblemen often refused to pay taxes, or asked for relief in exchange for their participation in wars. ${ }^{26}$ The king had direct control over crown lands, which were usually placed under the authority of a city, often founded by the king himself. ${ }^{27}$

The socio-economic structure I have described could imply conflict between the rent-paying peasantry on one side and the nobility and the state on the other, or between the nobility and the state over the distribution of this surplus between tax and rent. The social unrest that occurred during the reign of King Kawād (r. 488-496 and 498-531), associated, particularly by Arabic and Persian sources, with the religious movement of the Mazdakites, indeed seems to have been related to conflicts between these different players over landholding and the extraction of agricultural surplus. The Mazdakites had thought their name derived from the 'heretic' Zoroastrian Mazdak, who is believed to have predicated communal ownership of women and goods during the reign of Kawād. ${ }^{28}$ The use of words such as heresy or orthodoxy in defining the relationship between the Mazdakite movement and other forms of Zoroastrianism has recently been convincely challenged by Rezakhani, who points out how Zoroastrianism in late antiquity should not been seen as a monolitic orthodoxy, but as undergoing, in the late Sasanian and Early Islamic period, processes of transformation looking at defining an orthodoxy. The socio-religious nature of the movement remains ambiguous. Rezakhani writes:

2004), 245; Franz Altheim and Ruth Stiehl, Ein asiatischer Staat: Feudalismus unter den Sasaniden und ihren Nachbarn (Wiesbaden: Limes-Verlag, 1954), 11.

26 Rubin, "Nobility," 245; Altheim and Stiehl, Ein asiatischer Staat, 19.

27 Lukonin, "Institutions," 723, 726-727; Nina V. Pigulevskaja, Les villes de l'état iranien aux époques parthe et sassanide: contribution à l'histoire de la Basse Antiquité (Paris and Den Haag: Mouton, 1963), 186-187; Altheim and Stiehl, Ein asiatischer Staat, 18-19.

28 On the Mazdakites, see Zeev Rubin, "Mass Movements in Late Antiquity-Appearances and Realities," in Leaders and Masses in the Roman World: Studies in Honor of Zvi Yavetz, eds. Irad Malkin and Wolfgang Z. Rubinsohn (Leiden: Brill, 1995), 179-185; Patricia Crone, "Zoroastrian Communism," Comparative Studies in Society and History 36 (1994): 447462; Patricia Crone, "Kavād's Heresy and Mazdak's Revolt," Iran 29 (1991): 21-42; Ehsan Yarshater, "Mazdakism," in The Cambridge History of Iran, vol. 3, part 2, The Seleucid, Parthian and Sasanid Periods, ed. Ehsan Yarshater (Cambridge: Cambridge University Press, 1983), 991-1024; Otokar Klìma, Beiträge zur Geschichte des Mazdakismus (Praha: Verlag der Tschechoslowakischen Akademie der Wissenschaften, 1977); Otokar Klìma, Mazdak: Geschichte einer sozialen Bewegung im Sassanidischen Persien (Praha: Orientální ústav, 1957); Arthur Christensen, Le règne du roi Kawādh et le communisme Mazdakite (Copenhagen: A.F. Höst og Son, 1925). 
"Oddly, when one examines more closely the classical age of Mazdakism in the fifth and sixth centuries, one finds precious little evidence of its existence. As mentioned, there are virtually no sources from this time period which include Mazdak's name; nor is there a movement attributed to a single religious reformer, as Mazdak is later portrayed. For instance, the sixth-century Monophysite chronicler John Malalas presents a certain Boundos, a purported Manichaean originally living in Rome, to have been responsible for establishing the movement. Later Zoroastrian and Islamic authors, most notably al-Ṭabarī, also mention an immediate forerunner of Mazdak, a certain Zaradusht Khurragan, as the original initiator of what came to be known as Mazdakism." This kind of contraddictions of the sources has led a scholar such as Gaube to deny his existence: Mazdak is a creation of the early Islamic period to which the fifth-sixth century socio-religious movement was attributed. ${ }^{29}$

Traditional views on the Mazdakite movement have viewed the Mazdakite uprising largely as a peasant uprising ${ }^{30}$ and have considered Kawād to be in league with the Mazdakites and in support of them. ${ }^{31}$ The latter point is debatable: sources show many differences in the development of events. Some sixthcentury soruces refer to social disorders in the time of Kawād: the Syriac chronicle attributed to Joshua the Stylite (compiled around 5०7), before Kawād's second reign was over; Procopius' account based on information gathered during the war of 527-531, in which he participated as Belisarius' secretary; the history of Agathias, who died about 582 and who had access, not just to Procopius, but also to notes taken by a Christian interpreter from the Royal Annals of the Sasanids. As Patricia Crone has pointed out, the few extant sixth-century sources associate Kawād with women-sharing, but do not associate him with Mazdak..$^{32}$ For example, Pseudo-Joshua the Stylite writes concerning the reign of Kawād:

"And so, instead of speaking words of peace and salutation, as he ought to have done, and of rejoicing with him on the commencement of the sovereignty

29 Heinz Gaube, “Mazdak: Historical Reality or Invention?” Studia Iranica 11 (1982): 111-122.

30 Pigulevskaja, Les villes, 143-232; Klìma, Mazdak, 238-241.

31 This view is largely due to Klìma, Christensen and Nöldeke: Klìma, Mazdak, 131-148; Christensen, Le règne, 105-106; Theodor Nöldeke, Aufsätze zur persischen Geschichte (Leipzig: T.O. Weigel, 1887), 109. Kawād is associated with the Mazdakites, but with a different chronology (see discussion later) also by Rubin, "Mass Movements," 184-185.

32 Joshua the Stylite, Chronicle, ed. and trans. William Wright as: The Chronicle of Joshua the Stylite: Composed in Syriac A.D.507 (Cambridge: Cambridge University Press, 1882), ch. 20; Procopius of Caesarea, History of the Wars, vol. 1, ed. Henry B. Dewing (Cambridge, MA/London: Harvard University Press, 1914), I, v, 1-2 (30-32); Averil Cameron, "Agathias on the Sasanians," Dumbarton Oaks Papers 23 (1969): 128. 
which had been newly granted him by God, he irritated the mind of the believing emperor Anastasius with threatening words. But when he heard his boastful language, and learned about his evil conduct, and that he had re-established the abominable sect of the magi which is called that of the Zaradushtakan, (which teaches that women should be in common, and that everyone could sleep with whom he pleases), and that he had wrought harm to the Armenians who were under his sway, because they would not worship fire, he despised him". ${ }^{33}$

Procopius writes similarly of Kawād: "But as time went Cabades became more high-handed in the administration and of the government, and introduced innovations into the constitution, among which was a law which promulgated providing that Persians should have communal intercourse with their women, a measure which by no means pleased the common people. Accordingly they rose against him, removed him from the throne, and kept him in prison in chains". ${ }^{34}$

Furthermore, Kawād's 'communism of the women' is associated with the first phase of his reign (488-496), after which he was briefly deposed by the nobility. The events concerning Mazdak seem to have taken place in the 520 s or 53os. The rebellion appears to have been suppressed by Husraw, who took power in 531. Kawād probably allowed free carnal conjunction even for married wives, encouraging wife-sharing. The 'heretical' attitudes of Kawād seem to have generated discontent amongst the nobility. Common access to women represented, in any case, a menace both to the purity of noble lineages, and, in a much more practical way, to the repartition of possessions among the heirs of noble families, in particular in relation to landed property. ${ }^{35}$ Some Zoroastrian practices, such as next-of-kin marriages, seemed to be practiced to maintain land property within the same lineage and to prevent the dispersion of landed property; ${ }^{36}$ the pious foundations of the late Sasanian law (such as the foundation "for the soul" ruwān ray) were instituted for the same reason. ${ }^{37}$ Therefore, the heresy of Kawād may be considered, to a large extent, to be an attempt to

\footnotetext{
33 Joshua the Stylite, Chronicle, ch. 20.

34 Procopius, History of the Wars, I, v, 1.

35 Crone, "Zoroastrian Communism;" Crone, "Kavād's Heresy," 23-30.

36 Touraj Daryaee, "Marriage, Property and Conversion among the Zoroastrians: From Late Sasanian to Islamic Iran," Journal of Persianate Studies 6 (2013), 91-10o.

37 Maria Macuch, "Eine sasanidische Stiftung 'für die Seele'-Vorbild für den Islamischen waqf?" in Iranian and Indo-European Studies: Memorial Volume of Otakar Klíma, ed. Petr Vavroušek (Praha: Enigma, 1994), 163-180; Maria Macuch, "Sasanidische Institutionen in Früh-islamischer Zeit," in Transition Periods in Iranian History: Actes du symposium de Fribourg-en-Brisgau (22-24 Mai 1985) (Leuven: Peeters Publishers, 1987), 177-179.
} 
weaken property rights to land, giving the crown the advantage over control of the land. As we shall see, Kawād also started a cadastral survey for a land tax reform, but this seems to have happened after the first deposition of the king by the magnates of the empire, who were disturbed by his reforms.

As Zev Rubin has pointed out, nothing prevents us from seeing a complex and long development and presence on the social and religious scene of the Sasanian empire of the Mazdakite movement. The movement may at first have received some support by Kawād. Rubin points out that, in the initial phase, the Mazdakite movement may have been directed just against that part of the nobility which opposed the reforms: "if the present interpretation is correct, the Mazdakite movement is just one other example of the exploitation of economic and social oppression of an afflicted peasantry by a powerful and well organized religious sect in order to undermine an existing order". ${ }^{38}$ Wiesehöfer has argued that a part of the aristocracy had probably joined the sect, and that the Mazdakites were involved in the struggle for succession on the Sasanian throne. Concerning Kawād's accession to the throne, Wiesehöfer writes: "From the fact that, in our opening quotation, Pseudo-Joshua describes the new king as an anti-Roman friend to the Mazdakites only four years later, we may perhaps assume that the groups supporting Kawād were composed of those friendly to the Hephthalites and hostile to the Romans, on the one hand, and (even also aristrocratic) followers of Mazdak on the other. Since the at time both the anti-Roman and the pro-Mazdakite policy represented something new and Kawād was overthrown by revolt of the nobility as early as 496 and replaced by his brother Jamasp (Zamasphes), we can further assume that the change of foreign policy carried out by the king and probably also his ideas of religious-social reform met with decisive resistance not only in Constantinople (and probably also by the Zoroastrian priesthood)". ${ }^{39}$ With the change of reign from Anastasius to Justin in Byzantium, the relationship between the two powers may have improved. Kawād even suggested that Husraw, of whom he wanted to assure the succession to the throne, might be adopted by Justin. This new policy may have encountered the opposition of anti-byzantine factions in Persia, among which was the troop commander Seorses, friend of the Hephtalites and Mazdakites. Seorses was tried and executed: the charges included that he may have neglected Persian traditions, venerated new gods, and buried his wife, which could point to the possibility of following Mazdakites. ${ }^{40} \mathrm{Maz}-$

\footnotetext{
38 Rubin, "Mass Movements," 189.

39 Josef Wiesehöfer, "Kawad, Khusro I and the Mazdakites: A New Proposal," in Trésors d'Orient, ed. Philippe Gignoux (Paris: Peeters, 2009), 391-409, 400-401.

40 Wiesehöfer, "Kawad," 402.
} 
dakites would even have supported Kawus against Husraw for the succession to the throne. Wiesehöfer proposes that these events would have progressively radicalized the Mazdakite movement: so the suppression of the Mazdakite leadership and their noble support would have preceded a more popular insurrection, which is the one to which later sources refer. Social discontent and forms of rebellion continued in the kingdom of Husraw. Wiesehöfer's analysis takes into full account the sixth-century sources and solves the apparent problem that the more radical social aspects (except communism of women) is not mentioned there. However, Wiesehöfer has still to call for the existence of a more radical and popular phase. In my opinion, there is no contradiction between the possible involvement of factions of nobility and mass participation. The movement may have indeed started with a more religious and reforming agenda, and then became radicalized, as the social components of it may have varied.

A 'Mazdakite' rebellion, largely based in Iraq, ${ }^{41}$ indeed seems to have exploded during the reign of Kawād, but was later suppressed by Husraw (r. 531-579), his son and successor. Neither the doctrine of the Mazdakites nor the chronology of the events of the rebellion is entirely clear, but the rebellion can be safely assumed to have targeted the aristocracy, and was based on a religious belief that claimed common ownership of women, abolished private property, and advocated economic equality among men. ${ }^{42}$ In her recent book The Nativists Prophets of Early Islamic Iran, Patricia Crone refers to a persistent memory of Mazdakite rebellion even long after the conquest, as a memory of Mazdak himself, which seems to point indeed to the consolidation in the collective memory of the radical social clash. This is shown for example by the history of Ta'rïkh al-rusūlwa-l-mulūk written by al-Ṭabarī (839-923), who writes that Mazdak incited in this the lowly people (safala) against the upper class ('aliyya) ${ }^{43}$ Sixth-century sources allude to a condition of public unrest during the reign of Husraw: Agathias seems to describe the conditions of bitter social conflict and the probable presence of social banditry, ${ }^{44}$ a typical expression of social rebellion and opposition in rural societies. ${ }^{45}$

41 Crone, "Kavād's Heresy," 33; Klìma, Mazdak, 159-160; Christensen, Le règne, 99-10o.

42 Rubin, "Mass Movements," 179-183; Mansour Shaki, "The Social Doctrine of Mazdak in the Light of Middle Persian Evidence," Archív Orientální 46 (1978): 289-306; Werner Sundermann, "Neue Erkenntnisse über die Mazdakitische Soziallehre," Das Altertum 34 (1988): 183-188; Klìma, Mazdak, 183-214, 238-241. al-Ṭabarī, Annales quos scripsit Abû Djafar Mohammed Ibn Djarîr At-Tabarî, ed. M.J. de Goeje et al, (Leiden: Brill, 1879-1901), 1:893.

44 Cameron, "Agathias," 168.

45 Eric J. Hobsbawm, Bandits (New York: New Press, 2000), 20-21. 
From my perspective, two aspects of what appears to have been the social doctrine of Mazdak help us to form some hypotheses on the relationship between the Mazdakite movement and the social and economic structure of Sasanian Iraq. In his Kitāb al-Milal wa-l-nihal, ash-Shahrastānī (1086-1153) attributes to Mazdak the idea that wealth and women should be available to everybody, like air, fire and pasture $\left(k a l a^{3}\right){ }^{46}$ The reference to pasture seems to appeal to the usage of common land among rural populations, and therefore to rural folk as the main subscribers to Mazdak's ideology. Shaki's analysis of Middle Persian sources which refer to Mazdak's 'heresy,' and in particular to the Dēnkard, have also shed light on other interesting aspects of his social doctrine, and in particular on the nature of Mazdakite 'communism.' As we know, the Dēnkard is a religious encyclopedia first compiled by Ādurfarrbay i Farroxzādān, a Mazdean priest in the age of Caliph al-Ma'mūn (813-833), by assembling earlier, more ancient materials. ${ }^{47}$ The Dênkard indicates that the Mazdakites recognized matrilineal lineages. Communal property would have been administered through these lineage groups, whose members received shares of communal property in usufruct (in the Dēnkard: $\bar{o} b a r) .{ }^{48}$ The Dēnkard also add that the Mazdakites exalted the inferior ( $\bar{a} n \bar{\imath} k e h)$ and degraded the superior (ān ìmeh). ${ }^{49}$

Mazdakite 'communism' seems to have been based on the common management of property using the structures of the peasant economy, such as enlarged familial groups and communal management of pasture, as a model for 'communism'. The peasantry could have joined a rebellion against the nobility at the beginning of the sixth century as a reaction to the concentration of landed property and the strengthening of lordly rights over the land and its inhabitants that, as I mentioned at the beginning of this chapter, seems to take place from the fifth century in Sasanian Iraq. The egalitarian and communitarian character of the Mazdakite movement took as a model existing social structures of the countryside. At the same time the rebellion gave an ideological form to the discontent of the peasantry by building on social structures that were familiar to peasants. ${ }^{50}$ This is not a unique phenomenon. Forms of peasant rebellion in the nineteenth and early twentieth centuries also used religious forms of expres-

\footnotetext{
46 al-Shahrastānī, Kitāb al-milal wa-l-nihal, ed. W. Cureton (London: Society for the Publication of Oriental Texts, 1846), 193.

47 Carlo Cereti, La Letteratura Pahlavi (Milano: Mimesis, 2001), 41-78.

48 Shaki's transliteration of the Middle Persian text:Shaki, "Social Doctrine," 293-294 (quoted from 294).

49 Shaki, 296.

50 Similarly: Klìma, Mazdak, 196.
} 
sions or assumed a quasi-religious tone, and elaborated their vision of a future society on the basis of a projection of economic and social practices existing in their times. ${ }^{51}$

The crown also reacted to the increase in power and wealth of the aristocracy by trying to modify patterns of surplus distribution through a new system of tax assessment. A cadastre was started under Kawād and completed under Husraw Anōshag-ruwān. The cadaster provided the foundation for a reform of land tax assessment that led to stronger centralization of surplus extraction, with the bureaucracy more closely involved in the work of tax collection at every level. Tax was collected on the basis of a fixed amount of money or crops per unit of surface area. The tax rate varied according to the nature of the crops: for example tax rates for fields cultivated with wheat were different from rates for fields cultivated as vineyards. ${ }^{52}$

The Hazār Dādestān portrays a complex tax and administration system. The levying of taxes was in the hands of the state bureaucracy and the hierarchies of the Zoroastrian church: the mowbed, or 'chief priest,' and the rad, or 'spiritual master', seem to have played significant roles in tax collection..$^{53}$ The 'judge' (dādwar) had an extremely important role in land administration as he was competent in what we would call 'property rights:' this meant he knew what

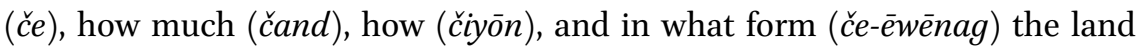
owners held the land. ${ }^{4}$ This, of course, covers similar competences to those of a modern-day cadastral bureau. The judge had authority over the tāsūg, which seems to have been the smallest administrative division above the vil-

$51 \quad$ Hobsbawm, Primitive Rebels, 57-92, 99.

52 Ulrika Mårtensson, "Discourse and Historical Analysis: The Case of al-Tabarî's History of the Messengers and the Kings," Journal of Islamic Studies 16 (2005): 287-331; Rubin, "Reforms," 227-297; Richard N. Frye, The History of Ancient Iran (Munich: Beck, 1984), 324-325; Mauro Grignaschi, "La riforma tributaria di Hosro I e il feudalesimo sassanide," in Accademia Nazionale dei Lincei: Problemi attuali di scienza e cultura: Atti del convegno internazionale sule tema La Persia nel medioevo (Roma, 31 marzo-5 aprile 1970) (Rome: Accademia Nazionale dei Lincei, 1971), 87-138; Mostafa Khan Fateh, "Taxation in Persia: A Synopsis from the Early Times to the Conquest of Mongols," Bulletin of the School of Oriental and African Studies 4 (1928):723-743; for a general discussion of sources and description of the administration: Andrea Gariboldi, Il regno di Xusraw dall'anima immortale. Riforme economiche e rivolte socialinell'Iran Sasanide del vi secolo (Milano: Mimesis, 2007), 178-179.

53 Farraxvmart ī Vahrāman, The Book, 294-297; Maria Macuch, Das sasanidische Rechtsbuch Mātakdān ihazār Dātistān (Teil II) (Wiesbaden: Kommissionsverlag Steiner, 1981), 51 (Middle Persian) and 189 (German translation); see also: Touraj Daryaee, Sasanian Persia: The Rise and Fall of an Empire (London: Tauris, 2009), 128-129.

54 Farraxvmart ī Vahrāman, The Book: 292-293; Macuch, Das sasanidische Rechtsbuch, 49-50 (Middle Persian) and 188 (German translation); see also Daryaee, Sasanian Persia, 133. 
lage (deh in Middle Persian). ${ }^{55}$ General financial functions seem to have been in the hands of the $\bar{a} m \bar{a} r g a r$, who was responsible for the reckoning and collection of taxes and for entries to - and disbursements from - the Royal Treasury, what was 'coming to and from the Palace' (in Middle Persian: ō shahigan madan ud az shahigan). The geographical extension of the powers of an āmārgar could vary, including one or more districts or provinces. ${ }^{56}$

Another consequence of Husraw's policies was that landholding was increasingly seen as a grant from the sovereign. This evolution changed the balance of power within the Empire and influenced patterns of landholding and land administration in Sasanian society. Status was increasingly based on the position granted by central government in connection with public function, and less on status at birth. The dahäqin (as they are called in Arabic sources, which often refer to them when discussing the situation of Iraq after the conquest), the 'petty nobility' of the Empire who owed their position to royal grants of village estates, played an important role in the tax collection. ${ }^{57}$ It seems that the state was able to reclaim the land grant upon the death of the grantee. ${ }^{58}$

Patricia Crone views the Mazdakite rebellion as a consequence of the tax reform, since a tax based on a fixed amount of cash or crops would have removed any certainty regarding that part of the harvest that was left for the peasants' survival, while payment in cash would have the additional disadvantage that the peasants were forced to sell their crops all at the same time, resulting in a price slump..$^{59}$ This view conflicts with the more commonly held opinion of the tax reform, and in general the centralized reforms of Husraw, as an outcome, rather than a cause, of the rebellion: their power crushed by the Mazdakites, the aristocracy would have accepted a 'Husrawian' restoration. As Zeev Rubin has pointed out in his important survey of Husraw's reforms: "no better explanation than the Mazdakite revolt has so far been offered for Husraw's success in implementing a reform which would have provoked a fierce opposition on the part of the nobility." ${ }^{\prime 0}$ Moreover, none of the sources refers to the

55 Daryaee, 125-126; Lukonin, "Institutions," 727; Richard N. Frye, The Golden Age of Persia: The Arabs in the East (London: Butler \& Tunner, 1975), 10.

56 Daryaee, Sasanian Persia, 132-133; Lukonin, "Institutions," 726.

57 Daryaee, Sasanian Persia, 29, 147-148; Gariboldi, Il regno di Xusraw, 31-32; Lukonin, "Institutions," 734; Altheim and Stiehl, Ein asiatischer Staat, 141.

$5^{8}$ Gariboldi, Il regno di Xusraw, 37-38; Farraxvmart ī Vahrāman, The Book, 188-189.

59 Crone, "Zoroastrian Communism;" Crone, "Kavād's Heresy," 33.

6o Rubin, "Reforms," 230; "Moreover any attempt to describe the reforms of Khusro as oppressive already during his own reign flies in the face almost all the evidence we possess about it," Rubin, "Mass Movements," 184. 
Mazdakite rebellion as a consequence of Husraw's reforms. ${ }^{61}$ On the contrary, as Pourshariati has noted, the Letter of Tansar - an important source, the last redaction of which can be dated to the sixth century - sees the establishment, by the crown, of reforms to keep great aristocratic families in check, including a census of the aristocratic families, as following a period of popular discontent and rebellion. Pourshariati has pointed out that this text contains what she calls "a veiled description of the Mazdakite rebellion," a description which is taken from the point of view of the 'ideology' of the crown. ${ }^{62}$ According to the Letter of Tansar, the great aristocratic families (ahl al-buyūtāt) became a cause of social disorder because of their greed, and they even began to earn money like tradesmen. At the bottom of the social scale, the populace ('a $\mathrm{a} m \mathrm{ma}$ ) and even the slaves (bandigān) rebelled. The king (in the Letter the king is Ardashīr, but, as Pourshariati points out, it is definitely a reference to Husraw), suppressed the riots, although he also appointed an inspector to survey noble families and to investigate their revenues. ${ }^{63}$

This seems to confirm that behind the revolt there was a process of accumulation of wealth and power by the aristocracy, and that the tax reform was a measure used to increase the crown's control over surplus extraction from the land in the hands of the nobility: this reform appears to have been linked to paternalistic measures toward the peasantry. Some sources seem to imply that Husraw's tax reform also included counter-measures to make it easier for the peasantry to bear the tax burden and to involve the different layers of society in the process of tax assessment. An important account of the tax reform is found in the historical work Tảikikh al-rusūl wa-l-mulük written by aț-Ṭabarī. He states that the judges in each administrative district received a copy of the tax register in order to prevent extortion. They also had to inform the king about the condition of the land in order to remit taxes in the case of a crop failure. ${ }^{64}$ Ibn al-Muqaffa' (d. 756/759), one of the most important translators of Middle Persian texts, stated that Husraw appointed officers to supervise crop failures and remit taxes in the case of shortages. ${ }^{65}$ The Sirat Anüshirwān presents the

61 For a survey, still indispensable to refer to Christensen, Le règne, 5-89. For Middle Persian sources: Daryaee, Sasanian Persia, 86-91; Shaki, "Social Doctrine."

62 Parvaneh Pourshariati, Decline and Fall of the Sasanian Empire: The Sasanian-Parthian Confederacy and the Arab Conquest of Iran (London: I.B. Tauris, 2008), 85-9o.

63 Pourshariati, Decline, 86-89; The Letter of Tansar, trans. Mary Boyce (Roma: Istituto Italiano per il Medio ed Estremo Oriente, 1968), 38-44.

64 al-Ṭabarī, Annales, 1:96o-963.

65 Reported in the Nihāyat al-'arab fíakhbär al-Fars wa-l-'arab; we can read the Arabic text in: Grignaschi, "La riforma tributaria," 135. On Ibn al-Muqaffa', see Ersilia Francesca, Il Principe e i Saggi: Potere e giustizia nel medioevo islamico (Monza: Polimetrica, 2005), 46- 
most interesting account of the reforms of Husraw. The Sirrat Anüshirwān is a first-person narrative of the main deeds of Husraw, probably based on ancient Middle Persian texts, ${ }^{66}$ preserved in the Tajārib al-umam written by Miskawayh (ca. 1030). ${ }^{67}$ It illustrates some interesting elements which help us to understand how the process of tax collection worked. The fiscal prefect ('ämil in Arabic or āmārgar in Middle Persian, as mentioned above), who was controlled by other functionaries chosen from the people to whom the king could grant his trust (and who are, later in the same text, called amin ahl al-balad: the trustworthy amongst the people of the country), and the taxpayers (ahl al-kharāăg) had the right to present complaints to the judge ( $q \bar{a} d \bar{l}$, probably the $d \bar{a} d w a r$ described above). The fiscal prefect, the judge, the amin ahl al-balad and the region's scribe (kätib al-küra, or shahr-dibìr, a royal tax collector sent to the province ${ }^{68}$ ) reported to the royal department. ${ }^{69}$ The taxpayers of each district gathered in the chief town with their leader ( $q \bar{a} i d$, probably the local lord), the judge and the amin to discuss their problems with the king's representatives. ${ }^{70}$ The judges also had to gather the inhabitants of the district without revealing their actions to the lords or fiscal prefects. ${ }^{71}$ Delegates from the district, even from the peasantry, were able to report to the government. ${ }^{72}$ Although the description of the tax reform in the Sirrat Anüshirwān is, to a large extent, ideological, it is, in broad terms, coherent with the structure of the Sasanian administration that emerged from the Hazār Dādestān: especially the duty of supervision that was accorded to the judges. This is a more general issue: I believe that caution in using later sources must be exercised, but we may still

47; Cereti, La letteratura pahlavi, 189; Charles Pellat, Ibn al-Muqaffa (mort vers 140/757) "conseilleur" du calife (Paris: Publications du Département d'Islamologie de l'Université de Paris-Sorbonne, 1976); Dominique Sourdel, "La biographie d' Ibn al-Muqaffa' d'après les sources anciennes," Arabica 1 (1954): 307-323.

66 This narrative is related to the epic narratives of the Xwadāy Nāmag tradition: for a short but good overview and bibliography see: Cereti, Pahlavi, 191-192.

67 On Miskawayh and his works, see Mohammed Arkoun, Contribution à l'étude de l'humanisme arabe au IVe/Xe siècle: Miskawayh (320/325-421) = (932/936-1030) philosophe et historien (Paris: Vrin, 1970).

68 Daryaee, Sasanian Persia, 54.

69 Mario Grignaschi, "Quelques spécimens de la littérature sassanide conservés dans les bibliothèques d' Istanbul," Journal asiatique 254 (1966): 18; Arabic text (manuscript facsimile): The Tajârib al-umam or History of Ibn Miskawayh, preface and summary by L. Caetani (Leiden: Brill, 1909), 1:19o.

70 Grignaschi, "Quelques spécimens," 20-21; The Tajārib al-umam, 194.

71 Grignaschi, "Quelques spécimens," 22; The Tajārib al-umam, 195.

72 Grignaschi, "Quelques spécimens," 20-21; The Tajārib al-umam, 196. See also Rubin, "Reforms," 273. 
compare them to earlier sources, possibly more or less contemporary to the events narrated, to understand what is the nature of the information they may have inherited, their strategy in transmitting them, and in general, to understand how reliable they may have been.

These paternalistic measures in any case did not change the very nature of the system of surplus extraction. On the contrary, they show the solidarity of interests between the aristocracy and the crown in reaffirming the continuity of surplus extraction through rents and taxes: Husraw is a reformer, but also a restorer. What the reforms show is a shift in the balance of power from the aristocracy to the crown, a shift that seems to have been facilitated by the eruption of social conflict through the Mazdakite rebellion. As Haldon points out, the relationship between the state and the ruling classes is always a contradictory and potentially antagonistic relationship: "tributary ruling classes and states function at the same level of primary appropriation, directly inducing the creation of surplus through their monopoly of various forms of non-economic coercion." ${ }^{73}$ But both the aristocracies and the crown were interested in the continuity of the flow of surplus extracted through coercive means. Husraw's reforms ensured that continuity, although changing the pattern of surplus distribution as a result of the changing balance of power.

\section{$2 \quad$ Land and Tax after the Arab Conquest}

The large and heterogeneous Sasanian Empire was not homogeneously affected by Husraw's reforms: recent research, and in particular the important work of Pourshariati, has shown the complexity of the political relationships on which the existence of the Empire was based. ${ }^{74}$ However, the hinterland of Iraq, where the Persian 'capital' Ctesiphon, the 'bread basket' of the Empire, was located, was more directly affected by the political and administrative reforms. The conditions of land tenure and surplus extraction under which Iraq was ruled after the Arab conquest seem to confirm this view. The land-tax assessment in Iraq after the conquest seems to have followed the general outline of Sasanian surplus collection, and the land tax remained the main source of income for the state. The main land tax, described in juridical sources as the tax imposed on the land of conquered populations who had not accepted Islam before the conquest and had not signed a special agreement (șulh), ${ }^{75}$ was

73 Haldon, The State, 156.

74 Pourshariati, Decline.

75 Concerning continuity and change in the tax assessment system after the Arab conquest, 
usually called kharā $\bar{g} .{ }^{76}$ The word kharāğ is surely of pre-Arabic origin (perhaps from Akkadian ilku). ${ }^{77}$ It passed to Arabic use probably through Sasanian administration. In the Hazār Dādestān we find the word harg, which likely indicates the land tax. In the documents of the Pahlavi archive in Berkeley we find a functionary called frašn-hargarīg, who probably had to identify the contributors subject to the land tax, since frašn means question and hargarig is related to harg. The Bactrian documents studied by Sims-Williams, which are in some cases dated from the years 110 to 549 (we are unsure of which year, likely the Sasanian era starting with the reign of Ardashir in 223), use the word vapyo (uargo), meaning rent. ${ }^{78}$ Kharäğ is compared or identified with rent in several later Arabic sources: Ash-Shāfiì wrote that kharāăğ means 'uğra, rent. ${ }^{79}$ The document from Khrasan studied by Khan, which dates from the Abbasid period between 755 and 777 (138-16o of the Islamic era), clearly uses the word kharäğ to indicate the land tax. Khan also hypothesized that the term originated in the administration of the Eastern provinces, and then spread to other provinces such as Egypt. ${ }^{80}$ Tax assessment on kharāğ land mainly followed a system called 'alā l-misāḥa: from a fixed portion of land (usually one ğarìb, i.e. $\left.1592 \mathrm{~m}^{2}\right),{ }^{81}$ a fixed amount of money and/or crops was collected. ${ }^{82}$ According to many of our sources (which unfortunately all come from the Abbasid period), the impost assessed varied with the kind of crops. ${ }^{83}$

see Campopiano, "L' administration;" Fred M. Donner, "The Islamic Conquests," in A Companion to the History of the Middle East, ed. Youssef M. Choueiri (Malden, MA.: Blackwell, 2008), 28-51; Fred M. Donner, The Early Islamic Conquests (Princeton: Princeton University Press, 1981), 239-240.

76 Michele Campopiano "State, Land Tax and Agriculture in Iraq from the Arab Conquest to the Crisis of the Abbasid Caliphate (Seventh-Tenth Centuries)," Studia Islamica 3 (2012): 35-80; Ghaida Khazna Katbi, Islamic Land Tax-Al'Kharäj: From the Islamic Conquests to the Abbasid Period (London: I.B. Tauris, 2010), 6, 14-19.

77 Morony, "Landholding," 138; Guitty Azarpay et al., "New Information on the Date and Function of the Berkeley Middle Persian Archive," Bulletin of the Asia Institute 17 (2003): 17-29; Wilfred van Soldt, "The Akkadian Legal Texts from Ugarit," in Trois millémaires de formulaires juridiques, eds. Sophie Démare-Lafont and André Lemaire (Genève: Droz, 2010), 85-124.

78 Nicholas Sims-Williams, Bactrian Documents from Northern Afghanistan, vol. 1, Legal and Economic Documents (Oxford: Oxford University Press, 2001), 90-91, 108-109.

79 Muhammad al-Shāfi '̄i, Kitāb al-umm, 3 (Cairo, 1321), 251.

8o Khan, Arabic Documents; Khan, "Newly Disovered," 208-210.

81 Walther Hinz, Islamische Masse und Gewichte (Leiden: Brill, 1955), 55, 65-66.

82 Michael G. Morony, Iraq after the Muslim Conquest (Princeton: Gorgias Press, 1984), 100.

83 Frederik Løkkegaard, Islamic Taxation in the Classical Period with Special Reference to Circumstances in Iraq (Philadelphia: Porcupine Press, 1978), 102-103; al-Muqaddasī, Kitāb Ahsan at-taqasìm fi márifat al-aqalìm, ed. M.J. de Goeje as: Descriptio imperii moslemici, 
Baber Johansen has argued that the Hanafite doctrine on land tax supported peasant ownership of land, because the payment of land tax proved the ownership of property rights. Therefore the Arab conquest would have favored peasant ownership of the land, in contrast to attempts to see them as simple serfs attached to the soil..$^{84}$ As the analysis of Michael Morony and a recent article by Jairus Banaji have pointed out, however, this is very difficult to believe. Both Morony and Banaji have shown how the landed elite of the Persian dahāqin stood surety for the taxes on their land: their village estates represented the prevailing form of land tenure in post-conquest Iraq. ${ }^{85}$ Village estates under the control of dahāqin were the normal agricultural and taxation units at the time of the Arab conquest: dahāqin helped in the collection of surplus and its transmission to the state in the form of taxes. ${ }^{86}$ This situation is reminiscent of the administrative practices known for early Islamic Egypt, where village headmen belonging to the Christian elites carried on the fiscal and administrative instructions of the pagarch. ${ }^{87}$ Yahyā ibn Ādam (758-818) affirmsThe Sawād was in the hands of the Nabateans who paid the kharāğ to the Persians. When the Muslims came, they left the Sawād to the Nabateans and dahäqin as they were, and imposed ğizyah on the heads of the men and the kharä $\breve{g}$ on the land. ${ }^{88}$ For the Arabs, the dahāqin played an important role in explaining the fiscal practices of the previous regime: for example, the caliph Mu'āwiya (r. 661-68o) is reported to have consulted them on the conditions for taxation and about where the register of crown lands was kept. ${ }^{89}$

The Arabs initially settled in Iraq as warrior minorities in garrison cities, such as Kufa or Basra, receiving payments ( $\left.a t a^{\top}\right)$ from the land tax. ${ }^{90}$ Arab set-

auctore Shams ad-dīn Abū Abdallah Mohammed ibn Ahmed ibn ab̄̄ Bekr al-Bannā alBasshārī al-Moqaddasi (Leiden: Brill, 1906), 133; Ibn Khurdādbih, Kitāb al-Masālik wa-lmamālik., ed. M.J. de Goeje as: Liber viarum et regnorum auctore Abu'l-Kasim Obaidallah Ibn Abdallah Ibn Khordadhbeh et Excerpta e Kitab al-Kharadj auctore Kodama ibn Dja'far (Leiden: Brill, 1889), 14.

84 Baber Johansen, The Islamic Law on Land Tax and Rent (London/New York/Sydney: Croom Helm, 1988), 7-19.

85 Banaji, "Aristocracies;" Morony, "Landholding," 139. See also Bas van Bavel, Michele Campopiano and Jessica Dijkman, "Factor Markets in Early Islamic Iraq, c. 6oo-110o AD," Journal of the Economic and Social History of the Orient 57 (2014): 262-289.

86 Daryaee, Sasanian Persia, 29, 147-148; Morony, "Landholding;" Altheim and Stiehl, Ein asiatischer Staat, 141.

87 Sijpesteijn, Shaping a Muslim State, 88-89.

88 Ibn Ādam, Kitāab al-kharāăğ, ed. Theodoor W. Juynboll as: Le livre de l'impot foncier de Yahyā Ibn Ādam (Leiden: Brill, 1896), 23 (Arabic text).

89 al-Ya'qubī, Tårīkh, ed. M.Th. Houtsma as: Historiae (Leiden: Brill, 1883), 2:258.

9o Hugh Kennedy, "Military Pay and the Economy of the Early Islamic State," Historical 
tlers inscribed on a payroll known as dīwān were entitled to these payments on the basis of their contribution in fighting for the Muslim cause. These payments were not, or at least not explicitly, salaries paid for service in the army, although they evolved into military wages. ${ }^{91}$ The surplus of the Sawād, the rural area of Iraq, represented a crucial source of income for the conquerors. ${ }^{92}$ The conquerors, although themselves socially differentiated due, for example, to different positions within the clans or their connection with the ruler etc., nonetheless represented the exploiting classes, in the sense that they lived off the surplus (in the form of tax or rents) extracted from the producing population of Iraq. Conflicts among sub-sections of the conquering elite were often related to the distribution of surplus among them: the opposition of the qurra $\vec{a}$, professional reciters of the Qu'ran, to 'Uthmān (r. 644-656), for example, originated from their desire to control the surplus of the Sawād. ${ }^{93}$ Even when they adopted an egalitarian rhetoric, ${ }^{94}$ early Islamic factions' struggles in Iraq often rested on control of the surplus extracted from the peasantry of the Sawād in the form of salaries or through rent by acquiring stronger property rights on landed estates.

Conflicts in surplus appropriation among different sectors of the ruling class in Iraq exploded after the affirmation of Umayyad power. Mu'âwiya seems to have paid close attention to the reclamation of the domains of the Sasanian kings, investigating, as mentioned above, where the register of Sasanian crown land was kept. Under his reign, crown lands from Iraq and neighboring regions are reported to have yielded a 100,000,00o dirhams in revenue, according to alYa'qūbī, whereas the land tax from the Sawād and al-Kūfa is reported to have been 120,000,00o dirhams. ${ }^{95}$ Extension of the crown land would have meant a reduction of the land from which the salaries were paid, since the yield of the crown land did no longer go to the dīwān but to the caliph's personal treasure

Research 75 (2002): 155-169; Hugh Kennedy, The Armies of the Caliphs: Military and Society in the Early Islamic State (London/New York: Routledge, 2001), 6o-74; Donner, Early Islamic Conquests, 237-239.

$91 \quad$ Kennedy, "Military Pay," 162.

92 Campopiano, "State, Land Tax and Agriculture," Studia Islamica 3 (2012): 35-80; Hugh Kennedy, "The Feeding of the Five Hundred Thousand: Cities and Agriculture in Early Islamic Mesopotamia," Iraq 73 (2011): 177-199.

93 Muhammad A. Shaban, Islamic History: A New Interpretation, vol. 1, A.D. 60o-750 (A.H.132) (Cambridge: Cambridge University Press, 1971), 67. See also Martin Hinds, "Kūfan Political Alignments and Their Background in the Mid-Seventh Century AD," International Journal of Middle East Studies 2 (1971): 346-367.

94 Louise Marlow, Hierarchy and Egalitarianism in Islamic Thought (Cambridge: Cambridge University Press, 1997), 93-116.

95 al-Ya'qūbī, Tàrīkh, 2:277-278. 
chest. Estates from crown lands (sawā $\bar{\imath} i$ ) were often apportioned to be granted as gifts for members or clients of the ruling family (on which they paid tax at a lower rate, 'ushr), which often represented an elite within an elite. This process began to expand under the governor 'Abd Allāh b. Amīr b. Qurayz (in office 650-656), who granted land to many of his relatives and mawā $\bar{l}^{96}{ }^{96}$ These grants were often related to projects of revivification of dead lands, from which lower tax rates were extracted, usually in the form of 'ushr, the tithe assessed on the land of the believers and amounting to half that of the kharäğ paid on other land. Such estates were often granted in the area near Basra, and were developed through slave labor, such as the Zanğ, African slaves. ${ }^{97}$

Political influence was a key issue in both acquiring and extending these concessions. An interesting example is provided by al-Balādhurī (d. 892) who described the reclamation project of Maslama (d. 738), the son of the Umayyad caliph 'Abd al-Malik, in southern Iraq during the reign of al-Walīd (r. 705-715) ${ }^{98}$ Maslama proposed the investment of money in a reclamation project, the cost of which was estimated to be about 3,000,0oo dirhams. Maslama asked that the land that remained under water was given to him as qațía in order to revive it. The reclamation project was successful, farmers were brought in to work this land, and many other people entrusted their estates (diyy $\left.\bar{a}^{c}\right)$ to Maslama for 'protection'.

Extension of the crown lands and land grants reduced the surplus available for payments to people inscribed in the dīwän, and led to conflicts with Kufan and Basran Arabs. Opposition to the Umayyads and their protégés was often expressed in religiously justified rebellions. In particular, Kharijite groups played an important role in their opposition to the early Umayyad caliphs: during the reign of $\mathrm{Mu}$ 'āwiya there were sixteen Kharijite uprisings in Iraq. ${ }^{99}$

96 Morony, "Landholding and Social Change," 211-213; Donner, Early Islamic Conquests, 242243 .

97 Alexandre Popovic, La révolte des esclaves in Iraq au III /IX siècle (Paris: Geuthner, 1976), 6o-62.

98 al-Balādhur̄̄, Kitāb Futūh al-buldān, ed. M.J. de Goeje as: Liber expugnationis regionum, auctore imámo Ahmed Ibn Jahja Ibn Djabir al-Beládsorí (Leiden: Brill, 1866), 294. This event has been broadly discussed by Hugh Kennedy, "Elite Incomes in the Early Islamic State," in The Byzantine and Early Islamic Near East, vol. 6, Elites Old and New in the Byzantine and Early Islamic Near East, eds. John Haldon and Lawrence I. Conrad (Princeton: Darwin Press, 2004), 21-22.

99 Thomas Sizgorich, Violence and Belief in Late Antiquity: Militant Devotion in Christianity and Islam (Philadephia: University of Pennsylvania Press, 2009), 196-23o; William F. Tucker, Mahdis and Millenarians: Shïite Extremistes in Early Muslim Iraq (Cambridge: Cambridge University Press, 2008), 3; Morony, Iraq, 468-478; William Montgomery Watt, “Khārijite Thought in the Umayyad Period," Der Islam 36 (1961): 216-217. 
Iraq was also a harbor for Alid movements. Among these movements we can recall the one led by al-Mukhtār (d. 687) which brought on a rebellion that expelled the governor 'Abd Allāh b. Mutī' from Kufa in 685. The non-Arab Muslim mawālī were the mainstay of al-Mukhtār's movement, but he was also able, for a short period, to attract the support of Kufan ashräf..$^{100}$ The instability of Iraq had already led to the location of Syrian troops, the main supporters of the Umayyads, in Iraq and the establishment of a new garrison town, Wāsiț. ${ }^{101}$ The Syrian troops had to be paid from the land tax income which was now partially diverted, at the expense of Iraqi Arabs. ${ }^{102}$

The extension of crown lands, the diffusion of land grants for Umayyad protégés and the presence of the Syrians exacerbated the hostility of Iraqi Arabs and dahāqin (afraid of losing their land to the new elites). This motivated the massive participation in the revolt led by Ibn al-Ash'ath (d. 704) against the Umayyad governor al-Hağğăğ (in office 694-714) in 701, when rebels seized the crown lands and destroyed the register. Both Kufans and Basrans joined the rebellion; the qurrä), who advocated that the early conquerors of Iraq were the only ones entitled to its revenues, were among the most motivated supporters of the revolt. This uprising led to the battle of Dayr al-Ğamăğim, culminating in victory for al-Hağğăğ. ${ }^{103}$ It is probable that Kufans stopped receiving their payments from tax collection after this rebellion. ${ }^{104}$

While extending the crown lands and land grants for family members, the Umayyads also tried to strengthen central control over surplus extraction from the remaining kharäğ-paying lands, probably with the aim of compensating income losses due to the lower tax-rates paid by the beneficiaries of land grants. For this reason, land surveys were effectuated. We know, for example, that a land survey in Northern Mesopotamia was carried out in 691$692,{ }^{105}$ and that a land survey of the Sawād was conducted in 105/723-724 by the governor 'Umar b. Hubayra (in office $720 / 721-724$ ) at the request of Yazīd II (r. $720-724) .{ }^{106}$ These attempts at the centralization of surplus extrac-

\footnotetext{
100 Tucker, Mahdis, 16-33; Morony, Iraq, 491-492.

101 Khalid Y. Blankinship, The End of the Jihad State: The Reign of Hisham Ibn 'Abd al-Malik and the Collapse of the Umayyads (New York: SunY Press, 1994), 58-59.

102 Kennedy, Armies, 40.

103 Kennedy, 39-40; Morony, "Seventh-Century Iraq," 161-162.

104 Kennedy, Armies, 40.

105 Chase F. Robinson, Empire and Elites after the Muslim Conquest: The Transformation of Northern Mesopotamia (Cambridge: Cambridge University Press, 2000), 44-50.

106 Wadād al-Qāḍī, "Population Census and Land Surveys under the Umayyads (41-132/661750)," Der Islam 83 (2006): 365. A similar process has been observed by Elton E. Daniel for Khurasan: "It is more likely that Umayyad attempts to survey land, draw up cadastres, and enforce the land tax led to dissent than their alleged impiety"; The Political and Social
} 
tion from kharāğ-paying lands were bound to create more discontent among the Iraqi Arabs and especially the Kufans. Once more the situation is comparable to Egypt, where Ummayad centralization policies also caused discontent and revolts. ${ }^{107}$ This was a consequence of the evolution of landholding at the end of the seventh and, especially, in the first half of the eighth century. We can infer from our sources that an elite of Arab landholders had been formed on kharäğ lands, through land purchases and the conversion of previously non-Muslim elites. Some anecdotes also confirm that Muslim landlords were purchasing land after the conquest. For example, Yahyā b. Ādamreports that a dihqān approached 'Abd Allāh b. Mas'ūd (d. 652/653), a companion of the prophet Muhammad, asking him to buy his land. The 'Abd Allāh accepted, provided that the old landlord would stay as a steward on the property and continue to pay kharāğ on the land. ${ }^{108}$ The fiscal rescript, attributed to 'Umar II (r. 717-720), affirms that conversion to Islam exempted individuals from the poll tax but not from the kharäğ, while the mawāti asked to pay 'ushr. ${ }^{109}$ The caliph also stressed that the property of people who had converted would remain $f a y^{\prime}$ if they accepted Islam after the conquest. ${ }^{110}$ Later sources tend to attribute prohibition of the sale of kharāğ land to 'Umar I: Yahyā b. Ādam, for example, wrote that 'Umar forbade to Muslims the acquisition of kharāă land (ard al-kharā $\breve{g})^{111}$ and Abū 'Ubayd (d. 838) said that the purchase of the land of the ahl al-dhimma was prohibited by 'Umar I. ${ }^{112}$ This seems to be an attempt to distinguish these policies from those of the Umayyads because of their infamy after the Abbasid revolution; to put them on the shoulders of 'Umar I would have given them legitimacy. ${ }^{113}$ Previous schol-

History of Khurasan under Abbasid Rule 747-820 (Minneapolis and Chicago: Bibliotheca Islamica, 1979), 196.

107 Sijpesteijn, Shaping, 94-105.

108 Ibn Ādam, al-Kharāğ, 39 (Arabic text).

109 Abdul Aziz Duri, "Notes on Taxation in Early Islam," Journal of the Economic and Social History of the Orient 17 (1974): 138-140.

110 Hamilton A.R. Gibb, "The Fiscal Rescript of 'Umar II," Arabica 2 (1955): 1-16.

111 Ibn Ādam, al-Kharāğ, 39.

112 Abū 'Ubayd, Kitāa al-Amwāl, ed. al-Ṭab`ah (Beirut: Dār al-Ḥadāthah, 1989), 156-157.

113 A similar case has been examined by Chase Robinson for Northern Mesopotamia: even Syriac sources, such as Michael the Syrian, sometimes attribute the land survey of 691692 , which is reported to have caused so much hardship for the taxpayers, to 'Umar I; Robinson, Empire and Elites, 44-50; compare with The Chronicle of Zuqnin, parts III and IV. A.D.488-775, trans. A. Harrak (Toronto: Pontifical Institute of Medieval Studies, 1999), 147-148. See also Moshé Sharon, "The Military Reforms of Abū Muslim, their Background and Consequences," in Studies in Islamic History and Civilization in Honour of Professor David Ayalon, ed. Moshé Sharon (Leiden: Brill, 1986), 115. 
arship has not emphasised that all the elements discussed above point to the emergence of a Muslim landed elite and a concentration of landed property in its hands from at least the beginning of the eighth century. This process may have been influenced by the need to acquire a stable source of revenue, independent from changes in the political system that could influence the patterns of distribution of the surplus through salaries or other grants by substituting one group of beneficiaries for another, as happened with the end of the payment of salaries to the Kufans. This evolution is extremely important: it means that significant sections of the Muslim elite depended on the appropriation of surplus through rents, rather than on its redistribution via the state by payments of salaries. This change will play, as we will see in the next part, a crucial role in determining reforms of tax assessments in the Sawād in the early Abbasid period.

So far we have discussed conflicts concerning the repartition of surplus among the elites in terms of salaries or land ownership (and therefore rents). However, this surplus originated from peasant producers who appear to have been a politically subordinate class, working the estates of large landlords, and from whom surplus, in the form of taxes, rents and labor, was extracted through coercion, in substantial continuity from the late Sasanian period through to the arrival of the Abbasids. ${ }^{114}$ The fact that legal theorists have discussed whether the peasants of the Sawād should be considered slaves seems to be an attempt to find a rationalization, in legal terms, for the conditions of Iraqi peasantry. ${ }^{115}$ According to Abū 'Ubayd, 'Umar I forbade the purchase of slaves from among the dhimmī (raqīq ahl al-dhimma) because these people were ahl kharāğ, people of the land tax, i.e. people subjected to the extraction of land tax. ${ }^{116}$ The people of the Sawad were also called slaves (ariqqa $a^{3}$ ) in a tradition reported by al-Ṭabarī in the Kitāb Ikhtiläf al-fuqahā' and attributed to Sharīk b. 'Abd Allāh al-Nakha'ī during the caliphate of al-Manșūr (r. 754-775).117

114 This also was ultimately the view of Michael Morony: "On the other hand, apart from a general tendency for both the daaqin and the peasants to take liberties in the confusion immediately after the conquest, it is clear that the attachment of a servile labour force to the land it worked (raqiq al-ard) merely survived in Muslim Iraq from the late Sasanian period on the estates of the dahāain" (Morony, "Seventh-Century Iraq," 165).

115 Morony, 165.

116 Abū 'Ubayd, al-Amwāl, 157.

117 Joseph Schacht, ed., Das Konstantinopler Fragment des Kitāb ihtilāf al-fuqahä’’ des Abū Ğafar Muhammad ibn Ğarīr aț-Tabarī (Leiden: Brill, 1933), 225. See also Chase F. Robinson, "Neck-Sealing in Early Islam," Journal of the Economic and Social History of the Orient 48 (2005): 412-417; Paul G. Forand, "The Status of the Land and Inhabitants of the Sawād during the First Two Centuries of Islām," Journal of Economic and Social History of the Orient 14 (1971): 33 . 
Social conflictuality between peasantry and the ruling classes seems to have been expressed specifically through fleeing the lands they cultivated and on which they had to pay taxes and rents. Peasant flights from the lands they cultivate is an expression of social conflict strictly linked to the nature of coercive surplus extraction. Under al-Hajjāj, force was used in order to bring them back to the land. ${ }^{118}$ When he seized power in 744, caliph Yazīd III (r. 744) promised not to impose excessive taxes on non-Muslims because otherwise they would flee their lands. ${ }^{119}$ The Syriac Chronicle of Züqnin, written at the end of the eighth century at the monastery of Zūqnīn, near Amida (currently Diyarbekir on the Tigris in Turkey) ${ }^{120}$ describes how, in $77^{2-773}$, an agent was sent over the entirety of Northern Mesopotamia to return every fugitive taxpayer to his region, under caliph al-Manșūr. ${ }^{121}$

\section{From the Advent of the Abbasid to the Zanğ Revolt}

The advent of the Abbasid revolution did not radically change patterns of landholding and land tax assessment, nor the social conflicts related to them. As in the previous centuries, conflicts among the elites were often related to problems of the redistribution of the surplus collected, by way of rents and taxes, from peasant production. It is interesting to see how Ibn al-Muqaffac, in his Risāla fi l-șahāaba, suggests to the caliph al-Manșūr that he should rely on the local Iraqis for government, because of their erudition and piety. He also reminds the caliph of the damage wrought on the local population by the Syrian troops, and of the risk presented in assigning responsibility for tax collection to the Khurāsānì troops who could take advantage of their position to increase the tax burden. ${ }^{22}$

Large sections of Iraqi Muslims once more felt that they were excluded from the inner ring of power, the politico-military elite represented by the Khurāsānī, the central bureaucracy and by Abbasid protégés. Conflicts between civil servants and the military arose from the administration of tax collection.

\footnotetext{
118 Forand, "The Status," 28.

119 al-Ṭabarī, Tảīikh, 2:1834-1835.

120 Mistakenly attributed in the past to Dionysius of Tell-Mahre (The Chronicle of Zuqnin, 1). On the importance of this source for the history of Northern Mesopotamia, see Robinson, Empire and Elites, 44-47.

121 The Chronicle of Zuqnin, 257-258.

122 Francesca, Il Principe, 12-15 (edition of the Arabic test of the Risāla); Muhammad Q. Zaman, Religion and Politics under the Early 'Abbāsids: The Emergence of a Proto-Sunnī Elite (Leiden: Brill, 1997), 82-85.
} 
As Hugh Kennedy points out: "since the civil administration collected taxes which paid the soldier's salaries, there was ample cause of disagreement,"123 but Iraqi Muslims also expressed their resentment over the increasing burden represented by the Abbasid elites. In some cases they did this by committing in large numbers to Alid uprisings, such as that led by Muhammad b. 'Abd Allāh (d. 762), "The Pure Soul" (al-nafs al-Zakiyya), in 762, which a large number of Basrans (who did not have a strong Alid tradition, in contrast to the traditional Alid 'nest' of Kufa) joined. ${ }^{124}$ The Alid program, with its egalitarian claims and 'messianic' expectations of the re-establishment of justice on earth, represented a strong ideological glue for the expression of malcontents among Islamic population. ${ }^{125}$ The Alid rebellion of Abū Saraya (d. 815) in 815 was also largely supported by the Kufans. However, this last rebellion was probably greeted with less enthusiasm by the wealthy leaders of the community, the ashräf, among which the landholding elite should probably be counted, and was more largely supported by the urban populace. ${ }^{126}$

The necessity to maintain good relationships between the new dynasty and the landholding elite of Iraq led to the redefinition of the system of surplus distribution. The land tax reform was based on a new system of tax assessment on kharāğ land in Iraq. According to al-Balādhurī, at the end of the reign of alManșūr the Muslims of Iraq asked for a change in tax assessment: "Yahyā ibn Ādam said, concerning the muqāsama in the Sawād: the people (nās) asked for this from the ruler in the last period of the caliph al-Manșūr's reign."127 Under al-Mahdī (r. 744-785), the new taxation system was enforced. Under this form of tax assessment, the muqāsama, instead of a fixed amount of money or crops, the taxpayers had to pay a share of the crop: one half of the crop for land irrigated by flooding, a third for land irrigated by waterwheel, and one quarter for land irrigated by animal-turned wheels, according to al-Māwardī

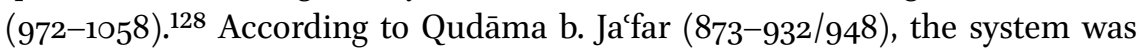
introduced thanks to the support of Abū 'Ubayd Allāh, ${ }^{129}$ the first author of

123 Hugh Kennedy, The Age of the Caliphs: The Islamic Near East from the Sixth to the Eleventh Century (London/New York: Longman, 1986), 139.

124 Tucker, Mahdis, 57; Hugh Kennedy, The Early Abbasid Caliphate: A Political History (London: Croom Helm, 1981), 200-203.

125 Tucker, Mahdis, 120-132.

126 Kennedy, Early Abbasid Caliphate, 208-210.

127 al-Balādhurī, Futūh, 271.

128 al-Māwardī, al-Aḥkām al-sulțāniyya wa-l-wilāyyā al-dīniyya (Beirut: Dār al-Kutub al-'Ilmiyya, 1980), 221.

129 Qudāma b. Ja'far (873-932/948), Qudāma Ibn Ja'far, Kitāb al-kharāj. Part seven and excerpts from Abū Yūsuf's Kitābal-Kharāj, translated and with introduction and notes by 
a book on kharāăg, who was appointed under al-Manșūr to the retinue of his heir al-Mahdī, and was the vizier under the government of the latter (probably appointed in 775 , died $786-787$ ). ${ }^{130}$ This information supports the idea of an agreement between the Muslim Iraqis (the ' $n \bar{a} s$ ' of Balādhurī's text) and a scholar who held a key position in the imperial administration (the vizier). Scholars who have investigated the economic views of Abū Yūsuf (d. 798) have explained his support of muqāsama as making it more bearable for the farmers. ${ }^{131}$ This is an important element: the local elite would definitely have preferred to avoid peasants fleeing from the land because of an excessive tax burden: Ibn al-Muqaffa', for example, complains of the oppressive effects of the 'alā l-misāha system and of the absence of clear regulation for the farmers. ${ }^{132}$ However, we should not forget the larger economic and social context in which the surplus extraction was situated: the dependent peasantry was mainly working the land of the Iraqi Muslim landed elite: the surplus extracted had to be shared between the landed elite, who was taking rent, and the state, which was taking taxes. Moreover, the Abbasids, who had been in power for about twenty years, had to maintain good relations with the Iraqi Muslims, who had offered valuable support to them in their rise to power. The muqāsama would have implied a less stable tax income for the state compared to the fixed amount of cash or crops collected under the 'ala l-misăha system, ${ }^{133}$ but it would have given the landlords the opportunity to share risks with the state in case of a bad harvest. This is the reason why some jurists, such as Abū 'Ubayd Allāh and Abū Yūsuf, supported the muqāsama. ${ }^{134}$ The use of a tax based on a share of the

Aharon Ben Shemesh (Leiden: Brill, 1965), 118 (Arabic text). This is also what Ibn al-Ṭiqțaqa writes: al-Ṭiqțaqa, al-Fakhri, trans. C.E.J. Whitting (London: Luzac \& Company, 1947), 176177; 'Abd al-Qādir Muhạmmad Māyū and Aḥmad 'Abd Allāh Farhūd, al-fakhrī fì l-ādāb as-sulhaniyya wa-l-duwwal al-Istāmiyya (Aleppo: Dār al-Qalam al-'Arabī, 1997), 179-18o.

130 Sabatino Moscati, "Abu 'Ubayd Allah," in Encyclopaedia of Islam, 2nd ed. (Leiden: Brill, 1960), 1:157-158.

131 Ramon Verrier speaks of a more just and fairtaxation; Ramon Verrier, Introduction à la pensée économique de l'Islam du VIII e au XV siècle (Paris: Harmattan, 2009), 69; "with the adoption of a proportional rate, variations in the price of grain will not significantly affect the burden on farmers;" Mohammed Nejatullah Siddiqi and Shaikh M. Ghazanfar, "Early Medieval Islamic Economic Thought: Abu Yousuf's (731-798AD) Economics of Public Finance," in Medieval Islamic Economic Thought: Filling the Great Gap in European Economics, ed. Shaikh M. Ghazanfar (New York: Routlege/Curzon, 2003), 216.

132 Francesca, Il Principe, 21 (Arabic text).

133 Also, Qūdama b. Ja'far affirms that the 'alā l-misāha would have protected the state against price fluctuations: Qūdama b. Ja far, Kitāb al-Kharāğ, 40 (English translation); 119 (Arabic text). Also al-Ṭabarī seems to be conscious of the stabilising effects of the 'alā l-misāha; Mårtesson, "Discourse," 287-331.

134 Qūdama b.Jacfar, Kitāa al-Kharāă, 40-41 (English translation); 119 (Arabic text); Abū Yūsuf, 
crops seems therefore mainly founded in the logic that a rationalization of the surplus distribution between landlord and state prevented conflicts between them. This attitude would have been in marked contrast to the more severe fiscal policies of the Umayyads, who drew up cadasters to firmly establish fiscal duties on the basis of the 'aläl-misāha tax assessment. However, the muqāsama system of tax assessment was not necessarily less oppressive for the peasants than the 'ala l-misăha system: it all depended on the share of the produce that was left in their hands.

Besides maintaining good relations with the Muslim landholders, the Abbasids also pursued land policies similar to those of the Umayyad in terms of grants of 'dead' land and the extension of crown lands. Landed estates previously granted to Umayyad protégés were given to people close to the Abbasids, as can be seen to have happened in southern Iraq, where the land was granted to people connected to the dynasty, who revived this land, and to expand cash crops through slave labor. ${ }^{135}$ These developments established the socioeconomic background of the great Zanğ revolt of 868-883.

The Zanğ revolt represents an interesting case within our overview of land tenure and social conflicts for different reasons. Slave labor represents intrinsic sociological and economic differences to the economic structure we have seen in most of Iraq which was based essentially on the coercive extraction of taxes and rents from producing peasants. Slavery in Islamic countries in the Middle Ages was essentially domestic slavery. However, the case of the Zanğ was different. They were employed to remove the crust of natron from the surface of the land, in order to reclaim the land for cultivation. They did not pay rents to the landlord: they are owned and fed by the landlord or by his leaseholders. They did not have the right to a share of the crops: crops are owned by the landlord or by his leaseholders. The landlords received their land grants because of their political connections, and could also keep slaves in subjection because the system of tax collections funded armies that would protect their interests. In southern Iraq, Zanğ rebellions are known to have happened as early as 689690 and $694 .{ }^{136}$

Many of the large estates in southern Iraq were planted with sugar cane. Sugar cane is a crop that needs to be watered frequently, resulting in saliniza-

al-Kharādj, 102-103 (English translation); Abū Yūsuf, al-Kharādj, 29 (Arabic text); see Johansen, Islamic Law, 54 .

135 Morony, "Landholding and Social Change," 215-217.

136 Popovic, La révolte, 62-63; see also Alexandre Popovic, "La révolte des Zandj, esclaves noirs importés en Mésopotamie: Problème des sources et perspectives," Cahiers de la Méditerranée 65 (2002): 159-167. 
tion of the soil. Slaves removed the salty soil in order to keep the land of southern Iraq cultivable, leading to a severe worsening of working conditions. ${ }^{137}$ The deterioration of their working conditions, and the probable increase in the number of slaves employed, as 'desalinization' works were doubtlessly very labor intensive, paved the way to the religious propaganda of 'Alī b. Muham$\operatorname{mad}(\mathrm{d} .883$ ), the leader of the Zang rebellion.

As Alexander Popovic has illustrated, it seems that there was not an innovative social doctrine in the teachings of 'Ali b. Muhammad. While the 'Master of the Zanğ' seems to have proclaimed the divine duty of punishing the masters of the slaves and improving the social conditions of the disgraced, his social message seems to have been limited to a 'reversal of fortune:' the Zanğ themselves would eventually become rich and even acquire slaves of their own. With its claims of social equality for all humans, the Mazdakite rebellion, which drew its support from the peasantry, offers a radically different ideological solution. It is possible that this ideological difference arose from the different social backgrounds of the two rebellions. The Mazdakite rebellion was probably supported by a peasantry from whom surplus was extracted in a coercive way, but within whose society the traditional ties of a peasant economy were relatively strong (economic organization based on lineage structures, collective exploitation of common land, etc.). Therefore, a plan of social reform based on these structures would have be 'organic' to fit the social reality of this peasantry. Zanğ slaves did not represent the totality of the rank-and-file of the so-called Zanğ-revolt, ${ }^{138}$ but they, and slaves of other backgrounds, were definitely the mainstay of the rebellion. This mass of 'déracinés' slaves, deprived of the social ties existing in peasant societies, but regimented in labor units under the cruel authority of their masters, would have not conceived any other social structure than the one in which they lived as victims: their program of social reform was simply to reverse their position from slaves to masters. Some peasant villages joined their rebellion, but the Zanğ often raided rural settlements and they also probably continued with the pre-existing structures of tax collection, in order to turn the surplus extraction to the advantage of their 'state.'139 When, in 878 , the Zanğ took al-Nu'māniyya and Jarjarāyā, the rural population of the Sawād, terrified by the rebels, fled toward Baghdad. ${ }^{140}$

137 al-Ṭabarī, Ta’rīkh, 3:1747-175o; see also Popovic, La révolte, 64-66.

138 Ghada H. Talhami, "The Zanj Rebellion Reconsidered," The International Journal of African Historical Studies 10 (1977): 443-461.

139 Popovic, La révolte, 161-162, 164-165.

140 al-Ṭabarī, Ta’īikh, 2:1932. 
However, despite the lack of any significant project of fundamental social reform, the Zanğ rebellion did contribute to changes in patterns of land exploitation in southern Iraq. The practice of reviving dead lands and tilling them through slave labor slowly came to an end. Social conflict once more proved to be one of the key factors in the evolution of economic structures. ${ }^{141}$

\section{Conclusions}

As it has been stated in the introduction, this volume explores the ways in which control was established in outside urban settlements in the late Antique and early Islamic world. The extraction and distribution of agricultural surplus was an important part of this control: the study of land tax and of land tenure is therefore crucial for the goals of this book. This chapter has shown how different land tax and land tenure systems could generate social conflicts which resulted in forms of resistance and rebellion which challenged political and economic control of the countryside. The concept of the tributary mode of production offers a valid intellectual framework to understand the recurring patterns of social conflicts in pre-industrial societies in which the political structures derived their financial support mainly from agriculture and the extraction of agricultural surplus based on direct or indirect coercive means. As my analysis has tried to show, social conflictuality within this economic structure could arise between the ruling elite and the peasant producers over surplus extraction, or in connection with patterns of surplus distribution among the elites receiving the surplus. These patterns have fundamental consequences for the organization of state administration and in defining the characteristics of the ruling elite. The appropriation of surplus production remains, in any case, the foundation for the existence of any ruling elite and any polity in a society resting on similar economic foundations. These economic foundations are not peculiar to the Middle East, but can be found in different societies across space and time. The tributary mode is therefore a unifying concept, offering us the chance to discard such distinctions as 'feudal' or 'Asiatic' (or their equivalent) modes of production, distinctions which often rest on Orientalist paradigms. This will therefore enable us to compare social structures and social conflicts across cultural boundaries and geo-ideological constructions.

141 Popovic, La révolte, 180-181. 


\section{Bibliography}

\section{Primary Sources}

Abū 'Ubayd (d. 838). Kitāb al-amwāl. Edited by al-Ṭab'ah. Beirut: Dār al-Ḥadāthah, 1989.

Abū Yūsuf. Kitāb al-kharādj. Cairo: Būlāq, 1886.

al-Balādhurī (d. 892). Kitāb Futūh al-buldān. Edited by M.J. de Goeje as: Liber expugnationis regionum, auctore imámo Ahmed Ibn Jahja Ibn Djabir al-Beládsorí. Leiden: Brill, 1866.

The Chronicle of Zuqnīn, parts III and IV. A.D.488-775. Translated by A. Harrak. Toronto: Pontifical Institute of Medieval Studies, 1999.

Farraxvmart ī Vahrāman (sixth century). The Book of a ThousandJudgments (a Sasanian Law-Book). Edited by Anahit G. Perikhanian. Costa Mesa: Mazda Publishers, 1997.

Ibn Ādam (758-818). Kitāb al-kharāğ. Edited by Theodoor W. Juynboll as: Le livre de l'impot foncier de Yahyā Ibn Ādam. Leiden: Brill, 1896.

Ibn Khurdādbih (820-911). Kitāb al-Masālik wa-l-mamālik. Edited by M.J. de Goeje as Liberviarum et regnorum auctore Abu'l-Kasim Obaidallah Ibn Abdallah Ibn Khordadhbeh et Excerpta e Kitab al-Kharadj auctore Kodama ibn Dja'far. Leiden: Brill, 1889.

Joshua the Stylite. Chronicle. Edited and translated by William Wright as: The Chronicle of Joshua the Stylite: Composed in Syriac A.D.507. Cambridge: Cambridge University Press, 1882.

The Letter of Tansar. Translated by Mary Boyce. Rome: Istituto Italiano per il Medio ed Estremo Oriente, 1968.

al-Māwardī (972-1058). al-Aḥkām al-sulțāniyya wa-l-wilāyyā al-dīniyya. Beirut: Dār alKutub al-'Tlmiyya, 1980.

The Tajârib al-umam or History of Ibn Miskawayh. Preface and summary by L. Caetani. 2 vols. Leiden: Brill, 1909.

al-Muqaddasī (945/946-991). Kitāb Ahsan at-taqasìm fì ma'rifat al-aqalìm. Edited by M.J. de Goeje as: Descriptio imperii moslemici, auctore Shams ad-dīn Abū Abdallah Mohammed ibn Ahmed ibn ab̄̄ Bekral-Bannāal-Basshārīal-Moqaddasi. Leiden: Brill, 1906.

Procopius of Caesarea. History of the Wars, vol. 1. Edited by Henry B. Dewing. Cambridge, MA/London: Harvard University Pres, 1914.

al-Shahrastānī (1086-1153). Kitāb al-milal wa-l-nihal. Edited by W. Cureton. London: Society for the Publication of Oriental Texts, 1846.

al-Shāfí̄ì, Muhammad. Kitāb al-umm, 3. Cairo, 1321.

al-Ṭabarī. Annales quos scripsit Abû Djafar Mohammed Ibn Djarîr Al-Tabarî. Edited by M.J. de Goeje et al. 15 vols. Leiden: Brill, 1879-1901.

al-Ṭiqțaqa (ca. 1262-1305). al-Fakhri. Translated by C.E.J. Whitting. London: Luzac \& Company, 1947 . 
al-Ya'qubī (d. 897). Ta’rīkh. Edited by M.Th. Houtsma as: Historiae. 2 vols. Leiden: Brill, 1883.

\section{Secondary Sources}

Altheim, Franz, and Ruth Stiehl. Ein asiatischer Staat: Feudalismus unter den Sasaniden und ihren Nachbarn. Wiesbaden: Limes-Verlag, 1954.

Arkoun, Mohammed. Contribution à l'étude de l'humanisme arabe au IVe/Xe siècle: Miskawayh (320/325-421) $=(932 / 936-1030)$ philosophe et historien. Paris: Vrin, 1970.

Azarpay, Guitty, Kathleen Martin, Martin Schwartz and Dieter Weber. "New Information on the Date and Function of the Berkeley Middle Persian Archive." Bulletin of the Asia Institute 17 (2003): 17-29.

Banaji, Jairus. "Aristocracies, Peasantries and the Framing of the Early Middle Ages." Journal of Agrarian Change 9 (2009): 59-91.

Bavel, Bas van, Michele Campopiano and Jessice Dijkman. "Factor Markets in Early Islamic Iraq, c. 6oo-1100 AD." Journal of the Economic and Social History of the Orient 57 (2014): 262-289.

Blankinship, Khalid Y. The End of the Jihad State: The Reign of Hisham Ibn 'Abd al-Malik and the Collapse of the Umayyads. New York: SunY Press, 1994.

Bourdieu, Pierre. "The Social Space and the Genesis of Groups." Theory and Society 14 (1985): 723-744.

Bourdieu, Pierre. "Social Space and Symbolic Power." Sociological Theory 7 (1989):14-25.

Cameron, Averil. "Agathias on the Sasanians." Dumbarton Oaks Papers 23 (1969): 67-183.

Campopiano, Michele. "Alā l-misāḥa and muqāsama Land Tax: Legal Theory and Balance of Social Forces in Early Medieval Iraq (Sixth to Eighth Centuries)." Journal of the Economic and Social History of the Orient 54 (2011): 239-269.

Campopiano, Michele. "State, Land Tax and Agriculture in Iraq from the Arab Conquest to the Crisis of the Abbasid Caliphate (Seventh-Tenth Centuries)." Studia Islamica 3 (2012): 35-8o.

Campopiano, Michele. "L' administration des impôts en Irak et Iran de la fin de l'époque Sassanide à la crise du califat Abbaside (vie-xe siècles)." In Lo que vino de Oriente, edited by. X. Ballestin and E. Pastor, 17-27. British Archaeological Reports, International Series 2525. Oxford: Archaeopress, 2013.

Cereti, Carlo. La Letteratura Pahlavi. Milano: Mimesis, 2001.

Christensen, Arthur. Le règne du roi Kawādh et le communisme Mazdakite. Copenhagen:

A.F. Höst og Son, 1925 .

Crone, Patricia. "Kavād's Heresy and Mazdak's Revolt." Iran 29 (1991): 21-42.

Crone, Patricia. "Zoroastrian Communism." Comparative Studies in Society and History 36 (1994): 447-462.

Daniel, Elton E. The Political and Social History of Khurasan under Abbasid Rule 747-820. Minneapolis and Chicago: Bibliotheca Islamica, 1979. 
Duri, Abdul Aziz. "Notes on Taxation in Early Islam." Journal of the Economic and Social History of the Orient 17 (1974): 136-144.

Daryaee, Touraj. Sasanian Persia: The Rise and Fall of an Empire. London: Tauris, 2009.

Daryaee, Touraj. "Marriage, Property and Conversion among the Zoroastrians: From Late Sasanian to Islamic Iran." Journal of Persianate Studies 6 (2013): 91-10o.

De Martino, Ernesto. Sud e magia. Milano: Feltrinelli, 1959.

De Martino, Ernesto. La terra del rimorso: contributo a una storia religiosa del Sud. Milano: Il Saggiatore, 1961.

Donner, Fred. The Early Islamic Conquests. Princeton: Princeton University Press, 1981.

Donner, Fred. “The Islamic Conquests." In A Companion to the History of the Middle East, edited by Youssef M. Choueiri, 28-51. Malden, MA: Blackwell, 2008.

Forand, Paul G. "The Status of the Land and Inhabitants of the Sawād during the First Two Centuries of Islām." Journal of Economic and Social History of the Orient 14 (1971): 25-37.

Francesca, Ersilia. Il Principe e i Saggi: Potere e giustizia nel medioevo islamico. Monza: Polimetrica, 2005.

Frye, Richard N. The Golden Age of Persia: The Arabs in the East. London: Butler \& Tunner, 1975.

Frye, Richard N. The History of Ancient Iran. Munich: Beck, 1984.

Gariboldi, Andrea. Il regno diXusraw dall'anima immortale. Riforme economiche e rivolte sociali nell'Iran Sasanide del VI secolo. Milano: Mimesis, 2007.

Gaube, Heinz. “Mazdak: Historical Reality or Invention?” Studia Iranica 11 (1982): 111122.

Gibb, Hamilton A.R. “The Fiscal Rescript of 'Umar II." Arabica 2 (1955):1-16.

Gignoux, Philippe. "Une nouvelle collection de documents en pehlevi cursif du début du VII ${ }^{\mathrm{e}}$ siècle de notre ère." Comptes-rendus de l'Académie des inscriptions et belleslettres 135, no. 4 (1991): 683-70o.

Gignoux, Philippe. "Aspects de la vie administrative et sociale en Iran du 7ème siècle.” In Contributions à l'histoire et la géographie historique de l'empire Sassanide, edited by Rika Gyselen, 37-48. Bures-sur-Yvette: Groupe pour l'étude de la civilisation au Moyen Orient, 2004.

Gramsci, Antonio. Quaderni dal Carcere. 4 vols. Torino: Einaudi, 1975.

Grignaschi, Mario. "Quelques spécimens de la littérature sassanide conservés dans les bibliothèques d' Istanbul." Journal asiatique 254 (1966): 16-45.

Grignaschi, Mauro. "La riforma tributaria di Hosro I e il feudalesimo sassanide." In Accademia Nazionale dei Lincei: Problemi attuali di scienza e cultura: Atti del convegno internazionale sule tema La Persia nel medioevo (Roma, 31 marzo-5 aprile 1970), 87-138. Rome: Accademia Nazionale dei Lincei, 1971.

Gyselen, Rika. La géographie administrative de l'empire sassanide: les témoignages sigillographiques. Paris: Groupe pour l'étude de la civilisation au Moyen Orient, 1989. 
Haldon, John. The State and the Tributary Mode of Production. London and New York: Verso, 1993.

Hinds, Martin. "Kūfan Political Alignments and Their Background in the Mid-Seventh Century AD." International Journal of Middle East Studies 2 (1971): 346-367.

Hinz, Walther. Islamische Masse und Gewichte. Leiden: Brill, 1955.

Hobsbawm, Eric J. Primitive Rebels: Studies in Archaic Forms of Social Movement in the 19th and 2th Centuries. Manchester: Manchester University Press, 1959.

Johansen, Baber. The Islamic Law on Land Tax and Rent. London/New York/Sydney: Croom Helm, 1988.

Kennedy, Hugh. The Early Abbasid Caliphate: A Political History. London: Croom Helm, 1981.

Kennedy, Hugh. The Age of the Caliphs: The Islamic Near East from the Sixth to the Eleventh Century. London/New York: Longman, 1986.

Kennedy, Hugh. The Armies of the Caliphs: Military and Society in the Early Islamic State. London: Routledge, 2001.

Kennedy, Hugh. "Military Pay and the Economy of the Early Islamic State." Historical Research 75 (2002): 155-169.

Kennedy, Hugh. "Elite Incomes in the Early Islamic State." In The Byzantine and Early Islamic Near East, vol. 6, Elites Old and New in the Byzantine and Early Islamic Near East, edited by John Haldon and Lawrence I. Conrad, 13-28. Princeton: Darwin Press, 2004.

Kennedy, Hugh. "The Feeding of the Five Hundred Thousand: Cities and Agriculture in Early Islamic Mesopotamia." Iraq 73 (2011): 177-199.

Khan, Geoffrey. "Newly Discovered Arabic Documents from Early Abbasid Khurasan." In From al-Andalus to Khurasan. Documents from the Medieval Muslim World, edited by Petra M. Sijpesteijn, Lennart Sundelin, Sofia Torallas Tovar and Amalia Zomeño, 201-215. Leiden: Brill, 2006.

Khan, Geoffrey. Arabic Documents from Early Islamic Khurasan. London: Khalili collections, 2007.

Khan Fateh, Mostafa. "Taxation in Persia: A Synopsis from the Early Times to the Conquest of Mongols." Bulletin of the School of Oriental and African Studies 4 (1928): $723-743$.

Khazna Katbi, Ghaida. Islamic Land Tax-Al'Kharāj: From the Islamic Conquests to the 'Abbasid Period. London: I.B. Tauris, 2010.

Klìma, Otokar. Mazdak: Geschichte einer sozialen Bewegung im Sassanidischen Persien. Praha: Orientální ústav, 1957.

Klìma, Otokar. Beiträge zur Geschichte des Mazdakismus. Praha: Verlag der Tschechoslowakischen Akademie der Wissenschaften, 1977.

Løkkegaard, Frederik. Islamic Taxation in the Classical Period with Special Reference to Circumstances in Iraq. Philadelphia: Porcupine Press, 1978. 
Lukonin, Vladimir G. "Political, Social and Administrative Institutions: Taxes and Trade." In The Cambridge History of Iran, vol. 3, part 2, The Seleucid, Parthian and Sasanian Periods, edited by Ehsan Yarshater, 681-746. Cambridge: Cambridge University Press, 1983.

MacKenzie, David N. A Concise Pahlavi Dictionary. London: Oxford University Press, 1971.

Macuch, Maria. Das sasanidische Rechtsbuch Mātakdān i hazār Dātistān (Teil II). Wiesbaden: Kommissionsverlag Steiner, 1981.

Macuch, Maria. "Sasanidische Institutionen in Früh-islamischer Zeit." In Transition Periods in Iranian History: Actes du symposium de Fribourg-en-Brisgau (22-24 Mai 1985), 177-179. Leuven: Peeters Publishers, 1987.

Macuch, Maria. Rechtskasuistik und Gerichtspraxis zu Beginn des siebenten Jahrhunderts in Iran: die Rechstsammlung des Farrohmard i Wahrāmān. Wiesbaden: Harrassowitz, 1993 .

Macuch, Maria. "Eine sasanidische Stiftung 'für die Seele'-Vorbild für den Islamischen waqf?" In Iranian and Indo-European Studies: Memorial Volume of Otakar Klíma, edited by Petr Vavroušek, 163-18o. Praha: Enigma, 1994.

Marlow, Louise. Hierarchy and Egalitarianism in Islamic Thought. Cambridge: Cambridge University Press, 1997.

Mårtesson, Ulrika. "Discourse and Historical Analysis: The Case of al-Tabarî's History of the Messengers and the Kings." Journal of Islamic Studies 16 (2005): 287-331.

Māyū, 'Abd al-Qādir Muhammad, and Aḥmad 'Abd Allāh Farhūd. al-Fakhrīfíl-ādāb assulhaniyya wa-l-duwwal al-Islāmiyya. Aleppo: Dār al-Qalam al-Aarabī, 1997.

Montgomery Watt, William. "Khārijite Thought in the Umayyad Period." Der Islam 36 (1961): 215-231.

Morony, Michael G. "Landholding in Seventh-Century Iraq: Late Sasanian and Early Islamic Patterns." In The Islamic Middle East, 700-1900: Studies in Economic and Social History, edited by Abraham L. Udovitch, 135-175. Princeton: Darwin Press, 1981.

Morony, Michael G. "Landholding and Social Change: Lower al-'Iraq in the Early Islamic Period." In Land Tenure and Social Transformation in the Middle East, edited by Tarif Khalidi, 209-222. Beirut: American University of Beirut Press, 1984.

Morony, Michael G. Iraq after the Muslim Conquest. Princeton: Gorgias Press, 1984.

Morony, Michael, Khodad Rezakhani. "Markets for Land, Labour and Capital in Late Antique Iraq, AD 200-70o." Journal of Economic and Social History of the Orient 57 (2014): 231-261.

Moscati, Sabatino. "Abu 'Ubayd Allah." In Encyclopaedia of Islam, 2nd edition, vol. 1. Edited by P. Bearman, Th. Bianquis, C.E. Bosworth, E. van Donzel, W.P. Heinrichs, 157-158. Leiden: Brill, 196o.

Nejatullah Siddiqi, Mohammed, and Shaikh M. Ghazanfar. "Early Medieval Islamic 
Economic Thought: Abu Yousuf's (731-798 AD) Economics of Public Finance." In Medieval Islamic Economic Thought: Filling the Great Gap in European Economics, edited by Shaikh M. Ghazanfar, 209-227. New York: Routlege and Curzon, 2003.

Nöldeke, Theodor. Aufsätze zur persischen Geschichte. Leipzig: T.O. Weigel, 1887.

Pellat, Charles. Ibn al-Muqaffa (mort vers 140/757) "conseilleur" du calife. Paris: Publications du Département d' Islamologie de l'Université de Paris-Sorbonne, 1976.

Pigulevskaja, Nina V. Les villes de l'état iranien aux époques parthe et sassanide: Contribution à l'histoire de la Basse Antiquité. Paris/Den Haag: Mouton, 1963.

Popovic, Alexandre. La révolte des esclaves in Iraq au III $/{ }^{e} X^{e}$ siècle. Paris: Geuthner, 1976. Popovic, Alexandre. "La révolte des Zandj, esclaves noirs importés en Mésopotamie: Problème des sources et perspectives." Cahiers de la Méditerranée 65 (2002): 159167.

Pourshariati, Parvaneh. Decline and Fall of the Sasanian Empire: The Sasanian-Parthian Confederacy and the Arab Conquest of Iran. London: I.B. Tauris, 2008.

al-Qāḍī, Wadād. "Population Census and Land Surveys under the Umayyads (41-132/ 661-750)." Der Islam 83 (2006): 341-416.

Qudāma Ibn Ja'far. Kitāb al-kharāj. Part seven and excerpts from Abū Yūsuf's KitābalKharāj, translated and with introduction and notes by Aharon Ben Shemesh. Leiden: Brill, 1965 .

Rezakhani, Khodadad, and Michael G. Morony. "Markets for Land, Labour and Capital in Late Antique Iraq, AD 200-700." Journal of Economic and Social History of the Orient 57 (2014): 231-261.

Robinson, Chase F. Empire and Elites after the Muslim Conquest: The Transformation of Northern Mesopotamia. Cambridge: Cambridge University Press, 2000.

Robinson, Chase F. "Neck-Sealing in Early Islam." Journal of the Economic and Social History of the Orient 48 (2005): 401-441.

Rubin, Zeev. "The Reforms of Khusrō Anūshirwān." In The Byzantine and Early Islamic Near East, vol. 3, States, Resources and Armies, edited by Averil Cameron, 227-297. Princeton: Darwin Press, 1995.

Rubin, Zeev. "Mass Movements in Late Antiquity-Appearances and Realities." In Leaders and Masses in the Roman World: Studies in Honor of Zvi Yavetz, edited by Irad Malkin and Z.W. Rubinsohn, 129-187. Leiden: Brill, 1995.

Rubin, Zeev. "Nobility, Monarchy and Legitimation under the Later Sasanians." In The Byzantine and Early Islamic Near East, vol. 6, Elites Old and New in the Byzantine and Early Islamic Near East, edited by John Haldon and Lawrence I. Conrad, 235-273. Princeton: Darwin Press, 2004.

Schacht, Joseph. Das Konstantinopler Fragment des Kitāb ihtilāf al-fuqahā' des Abū Ğafar Muḥammad ibn Ğarī aț-Ṭabarī. Leiden: Brill, 1933.

Shaban, Muhammad A. Islamic History: A New Interpretation, vol. 1, A.D.60o-750 (A.H.132). Cambridge: Cambride University Press, 1971. 
Shaki, Mansour. "The Social Doctrine of Mazdak in the Light of Middle Persian Evidence." Archív Orientální 46 (1978): 289-306.

Sharon, Moshé. "The Military Reforms of Abū Muslim, their Background and Consequences." In Studies in Islamic History and Civilization in Honour of Professor David Ayalon, edited by Moshé Sharon, 105-143. Leiden: Brill, 1986.

Sijpesteijn, Petra M. Shaping a Muslim State: The World of a Mid-Eighth-Century Egyptian Official. Oxford: Oxford University Press, 2013.

Sims-Williams, Nicholas. Bactrian Documents from Northern Afghanistan, vol. 1, Legal and Economic Documents. Oxford: Oxford University Press, 2001.

Sizgorich, Thomas. Violence and Belief in Late Antiquity: Militant Devotion in Christianity and Islam. Philadelphia: University of Pennsylvania Press, 2009.

Soldt, Wilfred van. "The Akkadian Legal Texts from Ugarit." In Trois millémaires de formulaires juridiques, edited by Sophie Démare-Lafont and André Lemaire. Genève: Droz, 2010.

Sourdel, Dominique. "La biographie d' Ibn al-Muqaffa' d'après les sources anciennes." Arabica 1 (1954): 307-323.

Sundermann, Werner. "Neue Erkenntnisse über die Mazdakitische Soziallehre." Das Altertum 34 (1988): 183-188.

Talhami, Ghada H. "The Zanj Rebellion Reconsidered." The International Journal of African Historical Studies 10 (1977): 443-461.

Tucker, William F. Mahdis and Millenarians: Shïite Extremistes in Early Muslim Iraq. Cambridge: Cambridge University Press, 2008.

Verrier, Ramon. Introduction à la pensée économique de l'Islam du VIII au XVe siècle. Paris: Harmattan, 20o9.

Weber, Dieter, Myriam Krutzsch and Maria Macuch. Berliner Pahlavi-Dokumente:Zeugnisse spätsassanidischer Brief-und Rechtskultur aus frühislamischer Zeit. Wiesbaden: Harrassowitz, 2008.

Wickham, Chris. Framing the Early Middle Ages: Europe and the Mediterranean. Oxford: Oxford University Press, 2005 .

Wiesehöfer, Josef. “Kawad, Khusro I and the Mazdakites: A New Proposal.” In Trésors d'Orient, edited by Philippe Gignoux, 391-409. Paris: Peeters, 2009.

Yarshater, Ehsan. "Mazdakism." In The Cambridge History of Iran, vol. 3, part 2, The Seleucid, Parthian and Sasanid Periods, edited by Ehsan Yarshater, 991-1024. Cambridge: Cambridge University Press, 1983.

Zaman, Muhammad Q. Religion and Politics under the Early Abbāsids: The Emergence of a Proto-Sunnī Elite. Leiden: Brill, 1997. 